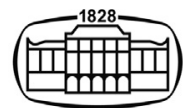

AKADÉMIAI KIADÓ

Central European

Geology

$64(2021) 2,113-132$

DOl:

10.1556/24.2021.00006

(c) 2021 The Author(s)

ORIGINAL RESEARCH

PAPER

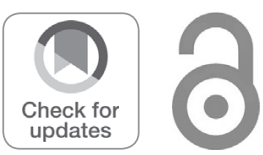

\section{Sedimentology and depositional system of a transitional shallow marine - coastal complex, Lower Visean deposits in the Central Volga-Ural Petroleum Province, Orenburg}

\author{
SZILVIA SZILÁGYI SEBŐK, ISTVÁN CSATÓ and \\ ISTVÁN NEMES* (1)
}

MOL Group, Budapest, Hungary

Received: August 14, 2020 - Accepted: September 16, 2020

Published online: May 13, 2021

\begin{abstract}
The paper presents a study of a Lower Carboniferous (Visean) clastic sequence commonly called Bobrikovsky Formation, deposited in the Volga-Ural Petroleum Province, Orenburg Region. Our investigation included sedimentological description of core samples from hydrocarbon wells and well $\log$ correlations. Facies were identified by well log patterns and calibrated by core sedimentology. The Bobrikovsky Formation is proposed to be interpreted as an overall transgressive-regressive succession in a nearshore-tidal environment. Transgressive lagoon-estuary and barrier island facies became regressional lagoon fill-type settings.
\end{abstract}

\section{KEYWORDS}

volga-Ural, Visean, Bobrikovsky Formation, sedimentary structure, facies interpretation, depositional model, depositional environment, marginal marine, coastal delta, tidal delta, barrier, lagoon

\section{INTRODUCTION}

The aim of this paper is to summarize the authors' current understanding of the depositional systems and sedimentary facies in the Lower Visean siliciclastic series, commonly called Bobrikovsky Formation in the study area in the Orenburg Region of the Central Volga-Ural Basin. The study was primarily based on quantitative well logs providing the necessary information for analysis of grainsize trends and to make correlations. Lithofacies and sedimentologic descriptions of cores were used to validate the main facies in six wells. The objective of the study is to build a coherent, simplified model that is able to explain and predict the spatial distribution of reservoir quality from a sedimentological and stratigraphic point of view, for oil and gas exploitation purposes. The goal of the interpretation was to establish a facies system, which is of practical use for the purposes of reservoir characterization; thus, it includes all the important sedimentary units that may play roles in hydrocarbon reservoir development and management. It also omits details that would unnecessarily increase computer run times and result and in an overly complicated model without leading to a better understanding of reservoir behavior, and an optimization of a field development strategy.

\section{DATA AND METHODS}

The sedimentological model is based on the analysis and correlation of subsurface data from three main sources: (1) lithofacies descriptions of cores, (2) core descriptions from a
* Corresponding author. MOL Group, E-mail: isnemes@mol.hu 
sedimentological point of view were used to set up a depositional model and to validate the main interpreted facies based on well logs and (3) electrofacies interpretation and correlation of well logs, mostly based on gamma ray and resistivity logs that provided abundant information for observing grainsize trends and making correlations. The correlated units were imposed on the seismic horizon slice corresponding to the Bobrikovsky Formation. In the case of clastic reservoir, cores were investigated from six wells, which were situated particularly in the northern part of Field A (Fig. 1). The results were compared with literature and modern analogs.

\section{GEOLOGIC SETIING}

The study area is located in the middle part of the VolgaUral Basin, south of the South Tatar Arch (Fig. 1). The basement deepens toward the North Caspian Basin and the Ural Mountains. The long geologic history of the VolgaUrals Basin can be grouped into a few major events. The Silurian was a period of oceanic rifting; thereafter a tectonic reorganization changed plate motions and the whole area underwent compression in the Lower Devonian (Zonenshain, 1984). The stress regime became extensional again in the Middle Devonian, when troughs formed in the interior of the plate. The Kazakhstan Plate and other fragments started to move toward the Russian Plate, and as a result, an overall compression developed in the Permo-Triassic (Zonenshain, 1984). This was the time when the Ural Foldbelt began to rise as part of the converging motions. Compression rejuvenated later in the Cenozoic Era.

The structural evolution of the study area can be divided into three main stages (Golov et al., 2000): A Middle Devonian extension, a passive margin subsidence in the Upper Devonian through the Permian, and a tectonic inversion in the Permo-Triassic, which was rejuvenated later in the Cenozoic (Fig. 2).

Four major sedimentary cycles are usually reported in literature in the Volga-Urals Basin. These are the EifelianTournaisian, Visean-Bashkirian, Moscovian-Artinskian, and post-Kungurian in the Paleozoic (Huvaz et al., 2007). Each of them may be further subdivided into shorter-term sequences that correspond to relative sea-level changes. The

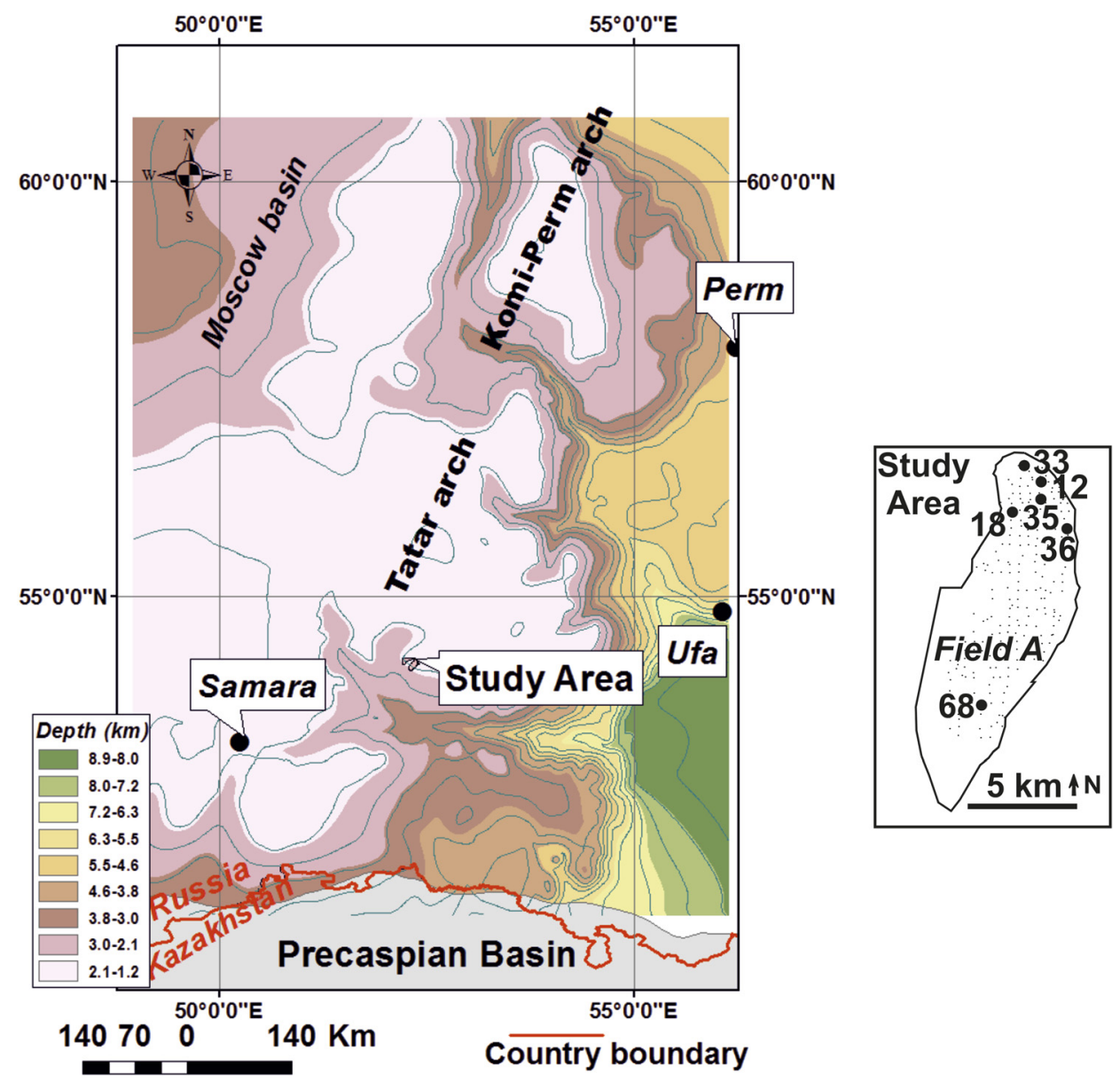

Fig. 1. Location of the study area in the Central Volga-Ural Basin. Basement map was constructed from IHS data (depth contours digitized after Peterson et al., 1983; IHS). The index map on the right shows the study area with the contour of the HC field (referred in the text as Field A). Over 300 wells (small dots) with well logs and six wells with cores (large dots labeled with codes, 33, 12, 35, 36, 18, 68) were investigated in this study 


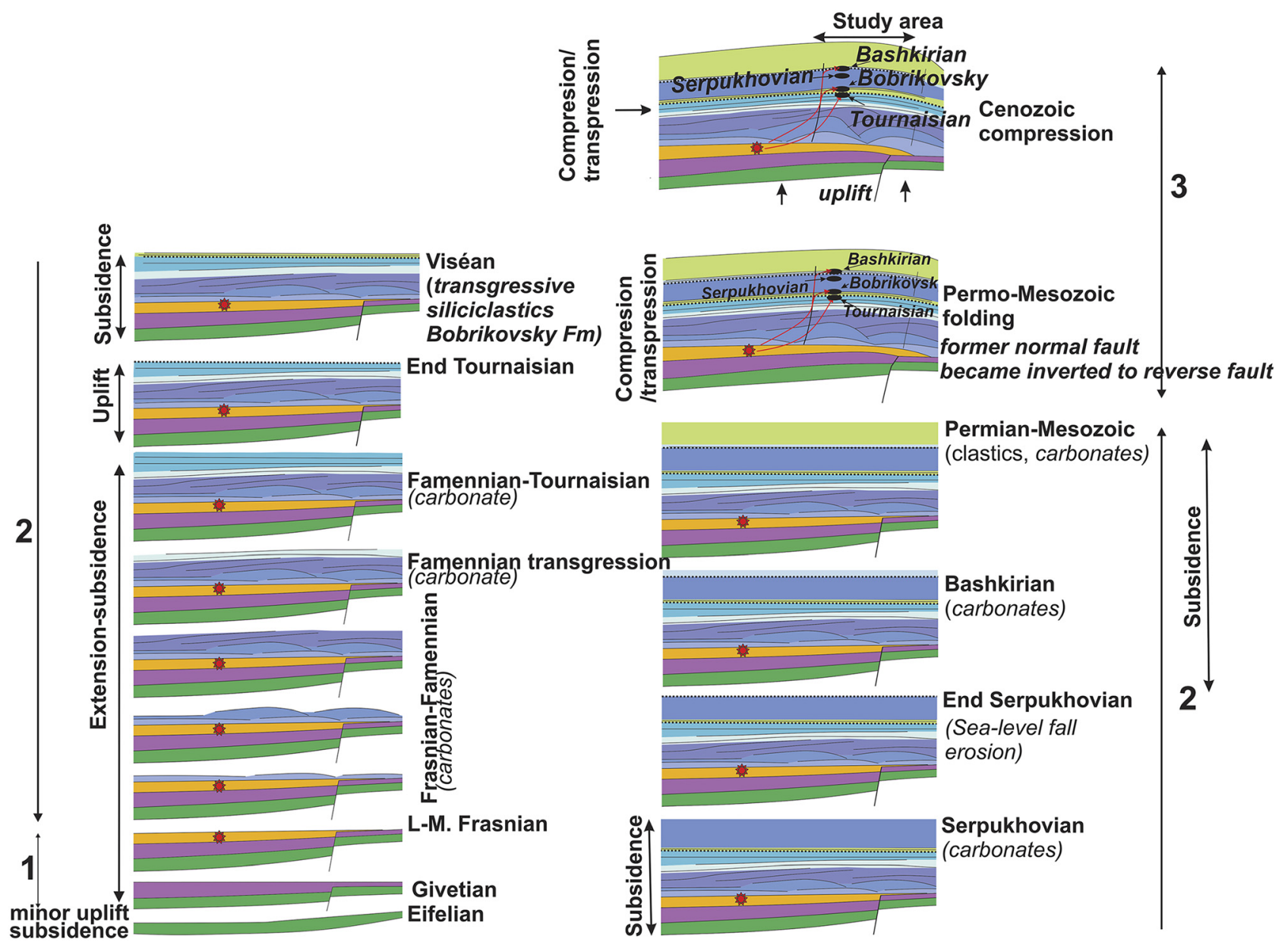

Fig. 2. Simplified model for the structural evolution of the study area. Interval 1: Middle Devonian extension; interval 2: passive subsidence; interval 3: tectonic inversion phases in Permo-Triassic and Cenozoic. (Red discs illustrate the hydrocarbon source)

main source rock zone is the Upper Frasnian Domanik Formation, and the reservoir intervals in the study area are Tournaisian, Visean, Serpukhovian (Namurian) and Bashkirian. The Tournaisian was the time of regional carbonate deposition, which ended suddenly and was replaced by siliciclastics in the Lower Visean. A substantial résumé was given by Meyerhoff (1984a, 1984b) regarding Carboniferous hydrocarbon production of the Eastern Hemisphere, in which the relationship of tectonics and oil and gas potential of Volga-Ural Region can be seen in a broader context, compared to other basins). The author emphasized that the most important Carboniferous producing unit in the VUB (Volga-Ural Basin) is the Visean, which contains the Bobrikovsky and Tulsky zones. This study focuses on the Lower Visean siliciclastic unit deposited above the Tournaisian unconformity, namely the Bobrikovsky Formation. In our study the Malinov Formation- which is a part of the Lower Visean Malinov- Bobrikov horizon and fills the Kama- Kinel depression in the Volga-Urals Basin in several hundreds of meters of thickness - is treated as a part of Bobrikovsky Horizon. A detailed tectonic scheme and stratigraphic features of the Orenburg region were given by Suharevich et al. (1975), Shudova (1975) and Travina (1975). A more detailed structural, tectonic and stratigraphic description of the study area is outlined by Nemes et al. (2020, in press).

\section{LITHOFACIES ASSOCIATIONS AND THEIR INTERPRETATION}

Our core investigation of lithofacies and sedimentary structures distinguished three facies within the Bobrikovsky deposits (1) barrier island, (2) tidal flat, and (3) distributary channel/tidal channel facies. The following section presents these main three facies associations in cores. The identified facies were calibrated with well logs and a larger-scale facies model was built, which will be presented in the section 'Stratigraphy and facies groups from well log correlations' in this paper.

\section{Barrier island facies}

Within the barrier island facies, four depositional environments were identified and interpreted. The barrier bar or barrier island environment was characterized by crossstratified, fine sandstone, with small-scale, low-angle cross stratification with thin mud drapes (Scr) (Fig. 3). 


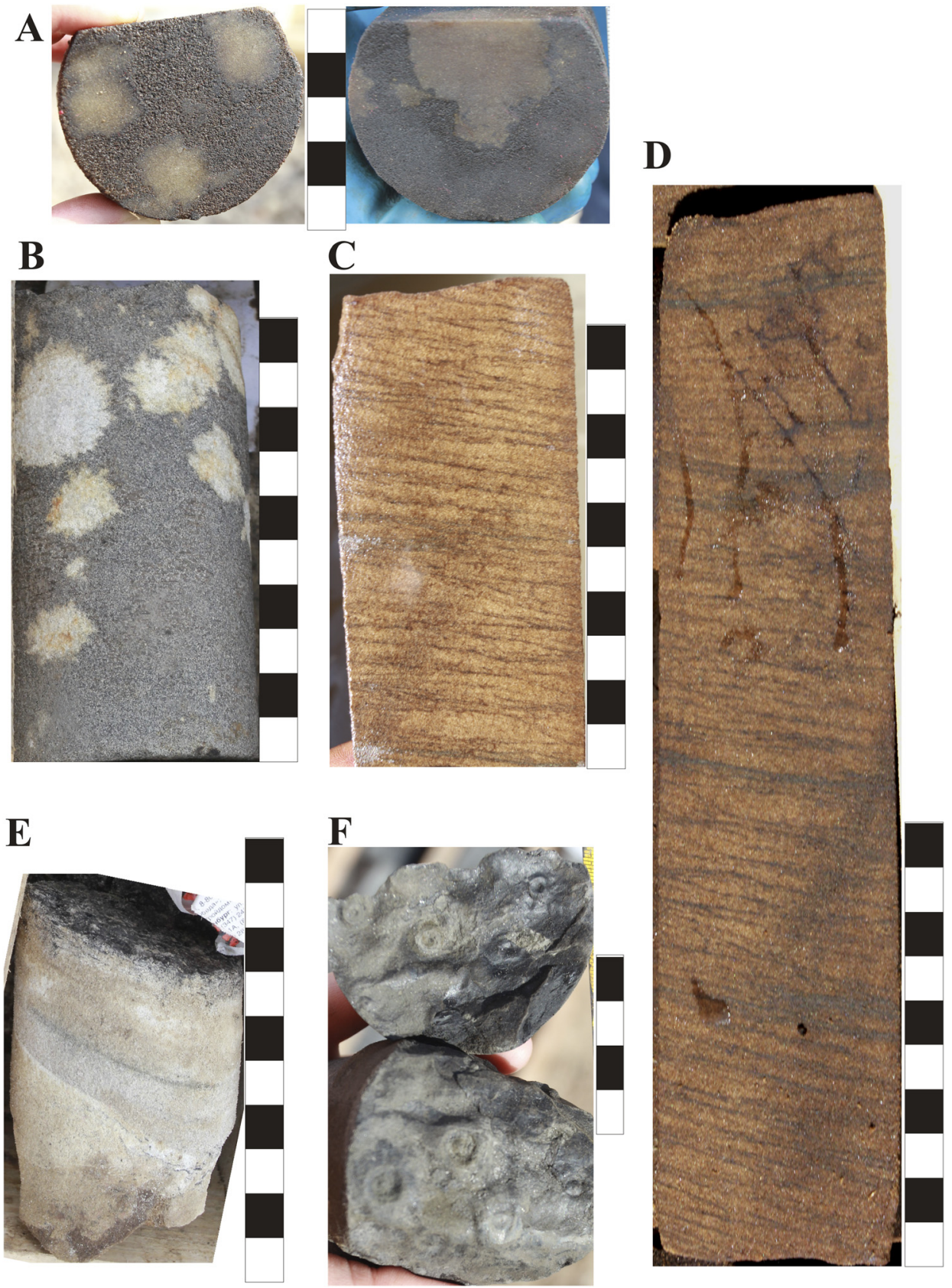

Fig. 3. Sediments of barrier bar/ barrier island environment of Bobrikovsky Formation. A-B: anhydrite nodules in coarse grained carbonaceous massive sandstone. C-D: low angle cross stratification with thin mud drapes deposited in upper flow regime conditions. E: amalgamation and erosional surfaces, coalified detritus. F: pieces of coalified Stigmaria ficoides trunk (scale bar is in centimetres).

Bioturbation was extremely rare; occasionally, laminae showed bidirectional fluid flow. The facies exhibited very fine lamination with low silt content and typically corresponded to upper-flow regime conditions with relatively rapid sedimentation. It is usually underlain by medium to coarse-grained massive sandstone (Smw) which is interpreted as a storm or washover unit, being an introductory episode of a barrier bar or barrier island-forming period, or a single event. Some cores indicate supratidal-intertidal sabkha-like environment with isolated anhydrite or gypsum nodules associated with emergent and semiarid or arid conditions. The mica content is significant. It is poorly cemented. The thickness of the unit does not exceed a few tens of centimeters; it sometimes contains well-preserved, coalified Stigmaria ficoides stems as a result of rapid burial processes in a shallow-water environment similar to coal forests. The drastic decrease in ichnodiversity compared to underlying sediments suggests stressful - most likely high transportation energy and brackish water-conditions. Wellpreserved plant fragments indicate relatively rapid burial processes. Trace and body fossils, as well as bioturbation, are rare (Fig. 3).

The lagoon or estuary environment is represented by black, microlaminated, dense, hard argillite with several 
biogenic siderite or pyrite nodules, sometimes microlaminated (Mlp) (Fig. 4). It is interpreted to have been deposited from slackwater fallout and deposited on the top of the Tournaisian unit.

The Glossifungites ichnofacies (Fig. 5) is also remarkable in a lagoonal or estuary black mudstone of the Bobrikovsky horizon, but only Rhizocorallium and Thalassinoides traces were observed with scratch marks and spreite based on Pemberton and Gingras (2005). Firm grounds of this ichnofacies may develop in marine intertidal and shallow subtidal zones, for instance low-energy situations such as salt marshes, mud bars of high intertidal flats, or in a shallow marine environment.

Regarding pyritized burrow fills, which were also common, it should be noted that Schieber (2002) emphasized the role of mucus and slime trails of marine benthos, as they serve as an initial food source and culture medium for infaunal microbial communities. Anaerobic bacteria can easily colonize surface sediments, because ions diffuse through mucus more slowly than through water, and the slime trails probably serve as a favorable anoxic condition. Schieber (2002) also noticed iron sulfide precipitation which also leads to very early encapsulation and preservation of microbial remains by way of microbial sulphate reduction. These sediments are the presumed muds of an estuary.

The salt marsh or swamp environment is characterized by silty claystone and mudstone which is strongly reworked and bioturbated (MSb) (Fig. 6). Horizontal lamination is also characteristic. Sometimes Teichichnus, Planolites and Chondrites traces can be identified. The producer organisms of Teichichnus, according to Knaust (2017), can be regarded as euryhaline organisms that are able to adapt to a wide range of salinity. For this reason, it has often been recognized in environments associated with reduced salinity. Such conditions are common in marginal marine settings. Tonkin (2012) found that Teichichnus seems to be a typical element of a siliciclastic sequence, where it often occurs in connection with delta deposits. Planolites also can be found in almost every depositional environment (Pemberton and Frey, 1982) and a good indicator of anoxic conditions, as well as Chondrites tracemakers, which tolerates well the highly variable redox conditions and reduced oxygen environments. Bromley and Ekdale (1984) wrote that the tracemakers' ability of Chondrites to tolerate oxygen deprivation is excellent. It can inhabit depositional environments from subtidal shelves to abyssal zones. The observed ichnogenera are the members of Cruziana
A

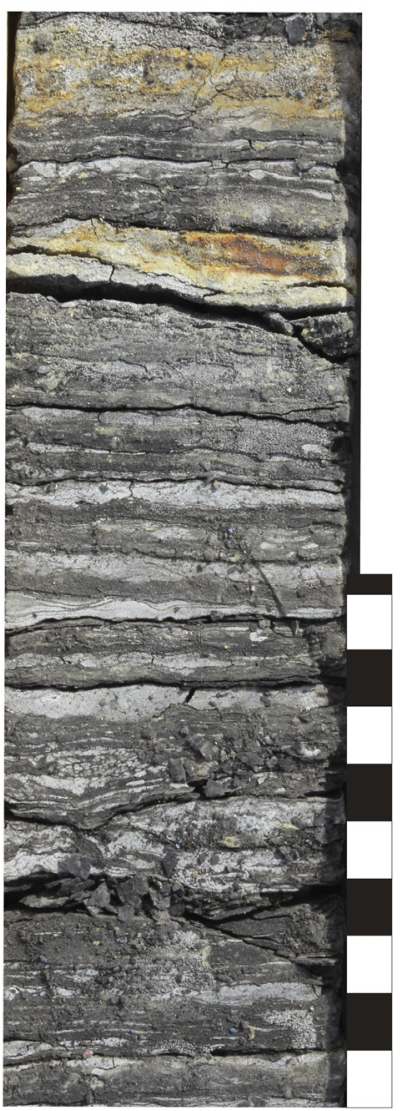

B

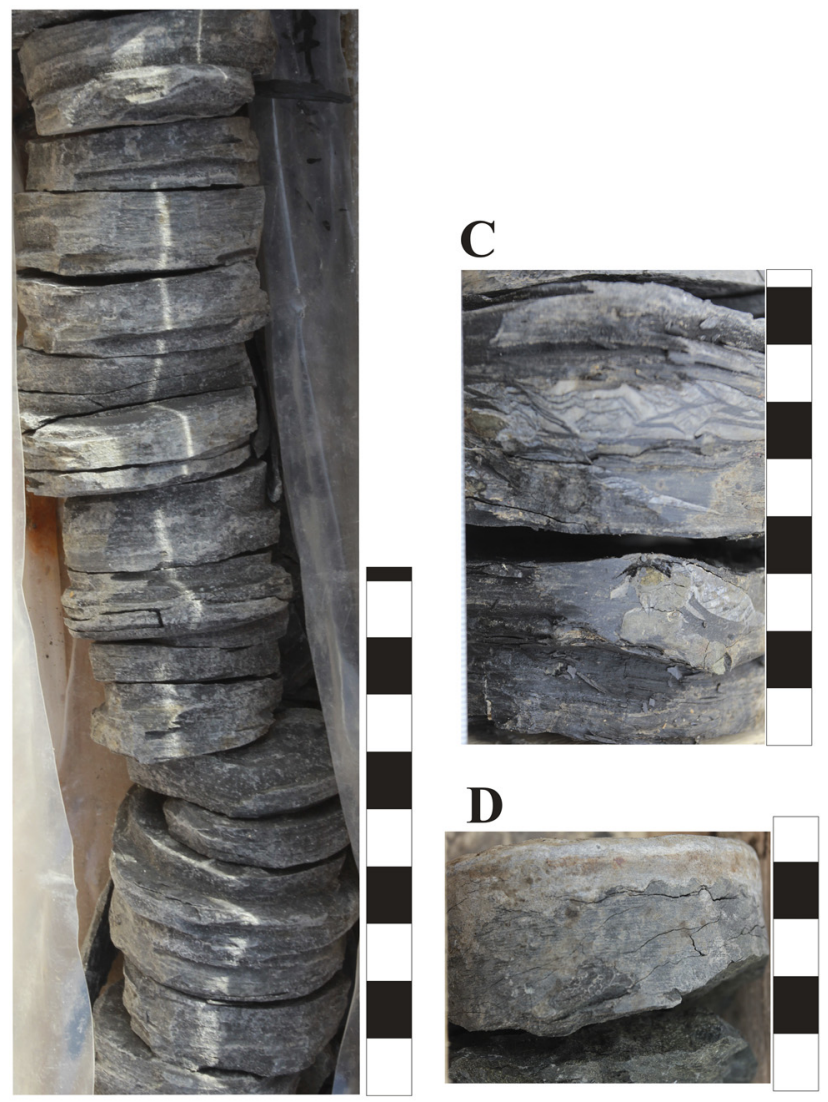

Fig. 4. Sedimentary structures of estuary/lagoon depositional environment in the transgressive cycle A: microlaminated mudstone and siltstone with horizontal and wavy lamination. B: Dense, hard microlaminated black shale with scattered pyrite C: Teichichnus 153 burrow fill, bioturbation, pyritized burrow fills and laminated, deformed anhydrite. D: load 154 structures and buried mud ripples (scale bar is in centimeters) 

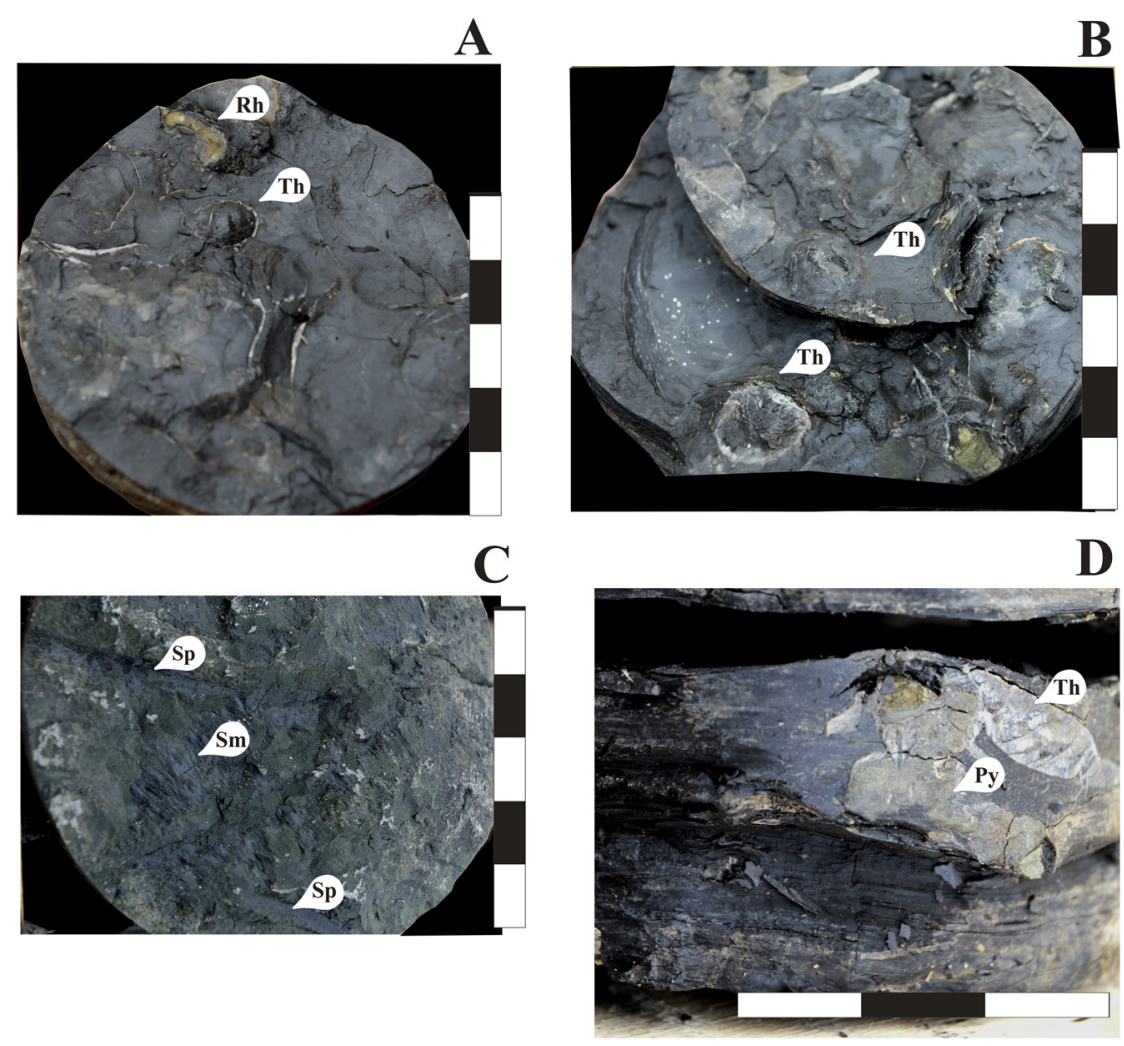

Fig. 5. Glossifungites icnofacies. A-B: Rhizocorallium (Rh) and Thalassinoides (Th) C: Scratchmarks (Sm) and spreite (Sp) D: Thalassinoides burrow fill (Th) and pyritized burrow fill (Py) (scale bar is in centimeters)

icnofacies, a marginal marine- nearshore shelf hosted ichnofacies.

The high biogenic pyrite content is typical in burrow adherent form both in vertical and in horizontal directions, as well as framboidal form. According to Bolucek and Ilhan (2006), the layered and lensoidal pyrites are syngenetic; the concretionary and authigenic pyrites are early diagenetic, and the fracture-fill pyrites are of epigenetic origin. The sediment consists of rooting structures and desiccation cracks. It was interpreted to have sedimented from lower flow-regime fluid flows. Well-preserved photosynthetic gas bubbles were found between laminae which prove the relatively shallow water depth. Skyring et al. (1989) found that the bubbles may be associated with various metabolic activities. Processes concerning carbon and sulfur metabolism take place in the upper few millimeters of mats, with photosynthesis occurring simultaneously with respiratory reactions. The sulfate reduction occurs close to, or within the phototrophic zone of microbial mats (Schieber et al., 2007). Schieber et al. (2007) suppose that the low diffusivity of gases through cyanobacterial slimes play an important role in the generation of gas bubbles. Based on the presented observations, a coastal swamp or salt marsh environment is assumed to have formed.

\section{Tidal flat facies}

Two depositional environments of tidal flat facies were interpreted which are discussed below.
The strongly reworked fine silty sandstone (SSb), which is originally composed of thinly laminated siltstone and bioturbated fine sandstone with low ichnodiversity (Fig. 7) is assumed to be (1) a tidal or subtidal mixed sand - mudflat environment. It contains two of the abovementioned firmground ichnogenera - Teichichnus, Planolites - and Glossifungites ichnofacies. The low taxonomic diversity of trace fossil assemblage indicates a tidal transgressive signature. The regular alternations of siltstone and fine sandstone also exhibit tidal influence in a low-energy environment with stressful conditions for benthic organisms. The flasered or wavy laminated, light grey fine sandstone is dense, hard with carbonaceous cement alternating with thin mud drapes and thin coalified laminae similar to algal mats. Climbing ripples are difficult to recognize within because of the starved nature and appearance. Small-scale flame and load structures are common as well as are syneresis cracks. Minor-scale fluid escape structures can also be seen. These post-depositional structures arose in soft, unconsolidated sediments as a result of pore-fluid escape due to the rapid deposition of overlying deposits (Sylvester and Lowe, 1978) subsequent upon tidal bores.

In the clastic Bobrikovsky unit, well-preserved tidal rhythmites were recognized with their special stacked cyclic alternations of fine calcareous sandstone and siltstone and thin dark grey or black mud drapes (Fig. 7). The cycles are well discernible, which validate the tidal influence of the subunit and are attributable to flood - slack-ebb-slack cycles. 

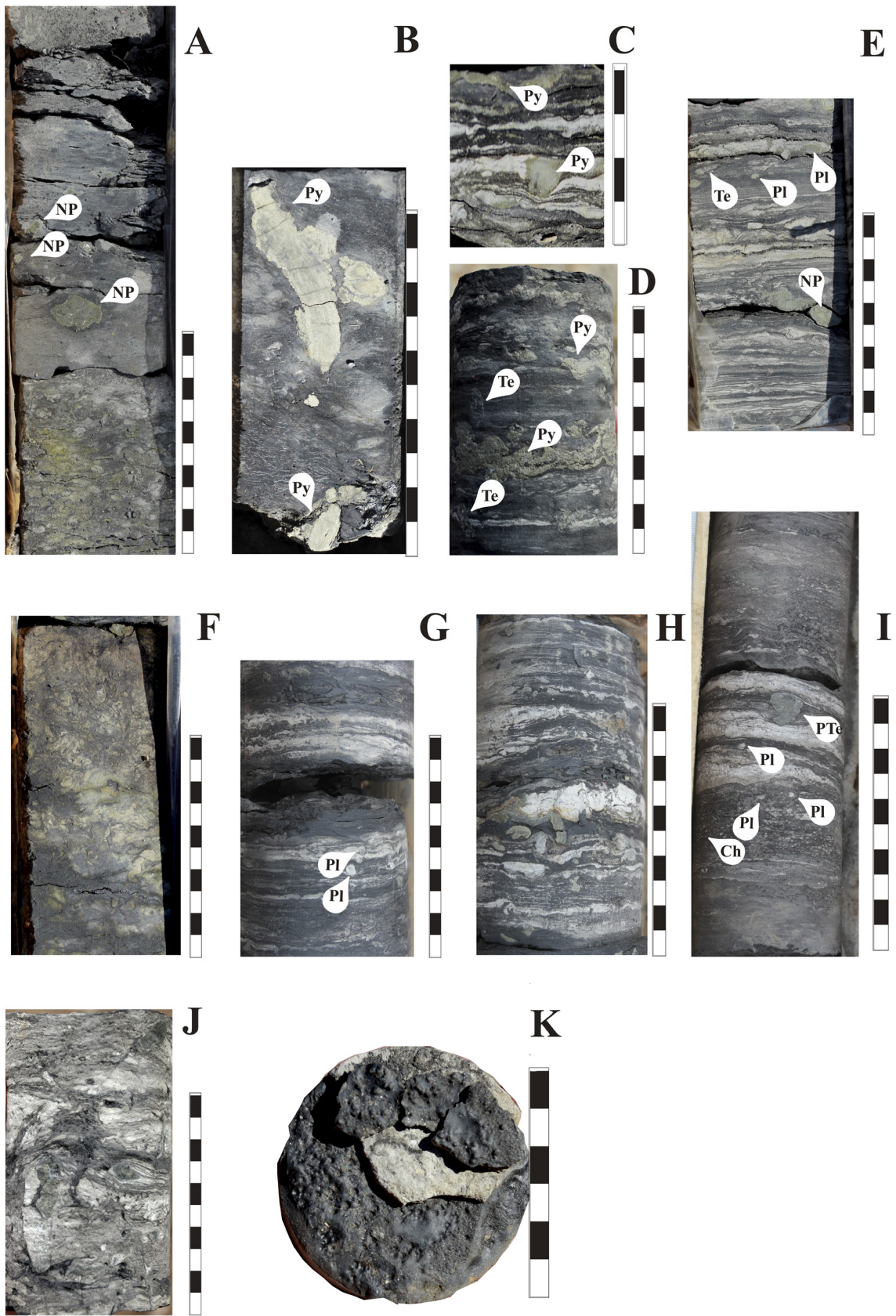

Fig. 6. Coastal swamp or salt marsh sediments of Bobrikovsky deposits. A: nodular pyrite (NP) in black shale. B: pyritized burrow fill (Py) CF: extensive bioturbation G: Planolites in silty shale H: pyritized burrow fills. J: fluid escape structures and disturbed, bioturbated siltstone and fine sandstone. K: photosynthetic gas bubbles and their imprints in the overlying sediments NP: nodular pyrite, Py: pyritized burrow fill, Te: Teichichnus, Pl: Planolites, Ch: Chondrites (scale bar is in centimeters)

The appearance of microbial mats in SSb and in Smh deposits is peculiar. These are treated as facies-dependent attributes in Homann et al. (2015), and Homann (2018). The wavy-lenticular type of fossil microbial mats in Fig. 7/C in intertidal facies corresponds to this analog.

Evidence of the rippled mud flat surface can be seen in Fig. 7/D, where buried and destroyed visible remnants of bigger mud ripples occur above a lenticular - flasered structure of sandstone and mudstone.

Sediments of the (2) tidal sandflat environment also showed up as weakly laminated medium sandstone with sharp top and base (Smh) (Fig. 8). It is underlain and overlain by black silty mudstone or claystone and contains very thin coal interbeds, mud drapes and microbial mats 

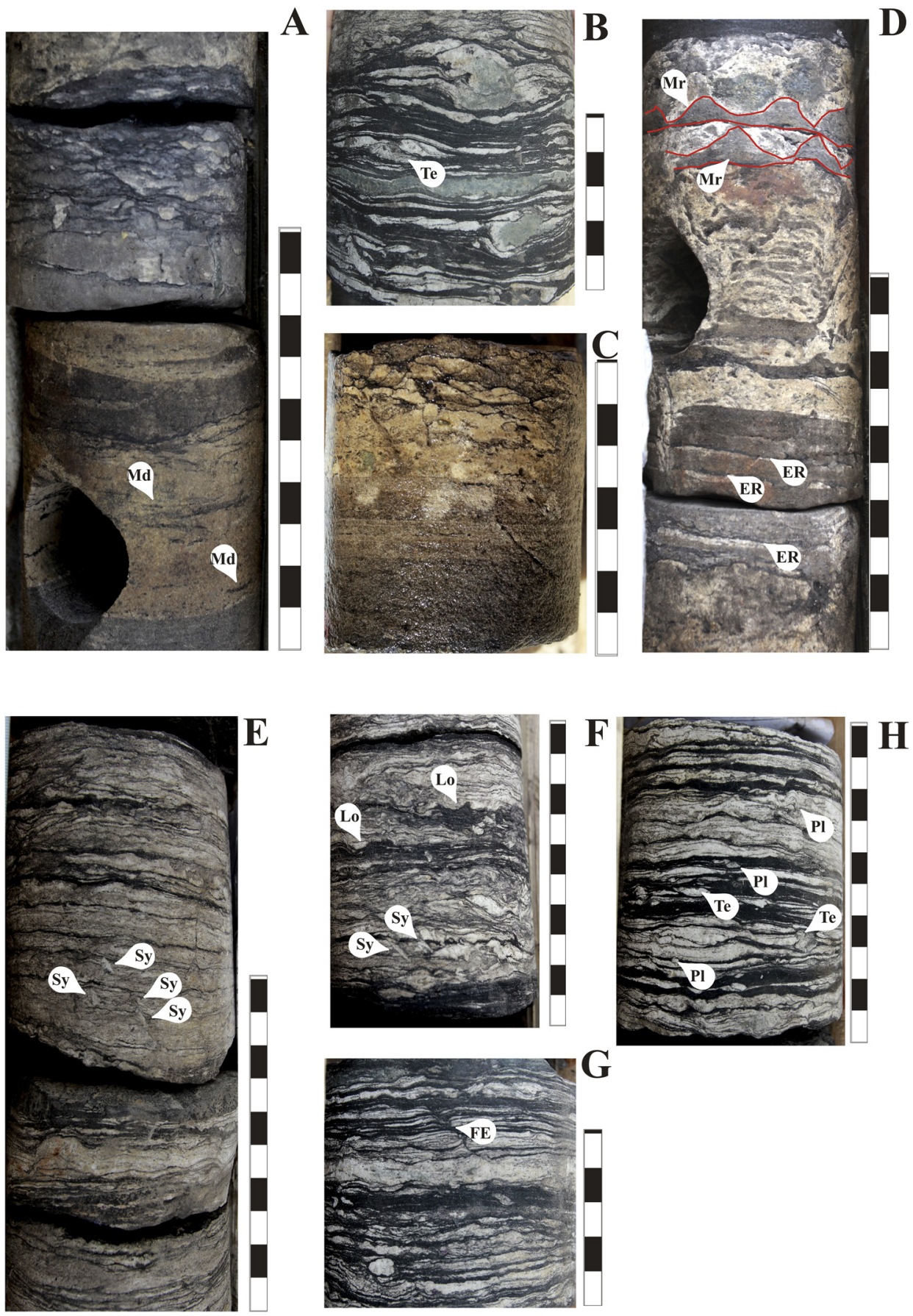

Fig. 7. Sedimentary structures of tidal mixed sand-mudflat sub-environments in Bobrikovsky clastic sequence. A: mud drapes (Md) in coarse sandstone B: Teichichnus burrows (Te) and pyritized burrow fills in bioturbated, wavy laminated sandstone C: coalified microbial mats in the top D: Erosional surfaces (ER) in mudstone, flasered- lenticular bedding, mud ripples (Mr) E-F: Tidal rhythmites with syneresis cracks (Sy) and load structures (Lo) G: fluid escape structures and starved climbing ripples in bioturbated, wavy laminated sandstone H: Planolites (Pl) and Teichichnus (Te) burrows in tidal rhythmites (scale bar is in centimeters)

with shallow marine-marginal marine ichnofacies. The upper part contains bioturbated and disturbed calcareous sand, possibly Diplocraterion burrows (Fig. 8A.). Diplocraterion due to its ability of tolerating reduction of salinity and energy fluctuations corresponds to a brackish or reduced salinity water and dysoxic environment, commonly recorded in marginal marine environments, such as tidal settings and estuaries (Buatois et al., 2005; Knaust, 2017). Mainly horizontal and/or wavy lamination is described with common coal interbeds (Fig. 8B-E).

Calcareous sandstone (Scalc) with medium-grained silty sandstone with slumping structure was also observed. It is disturbed, intensely bioturbated and extremely burrowed, which almost destroyed the original lenticular structure (Fig. 8/F-H). Burrowing is more pronounced towards the bottom and refers to escape burrows. It is underlain by the 
A
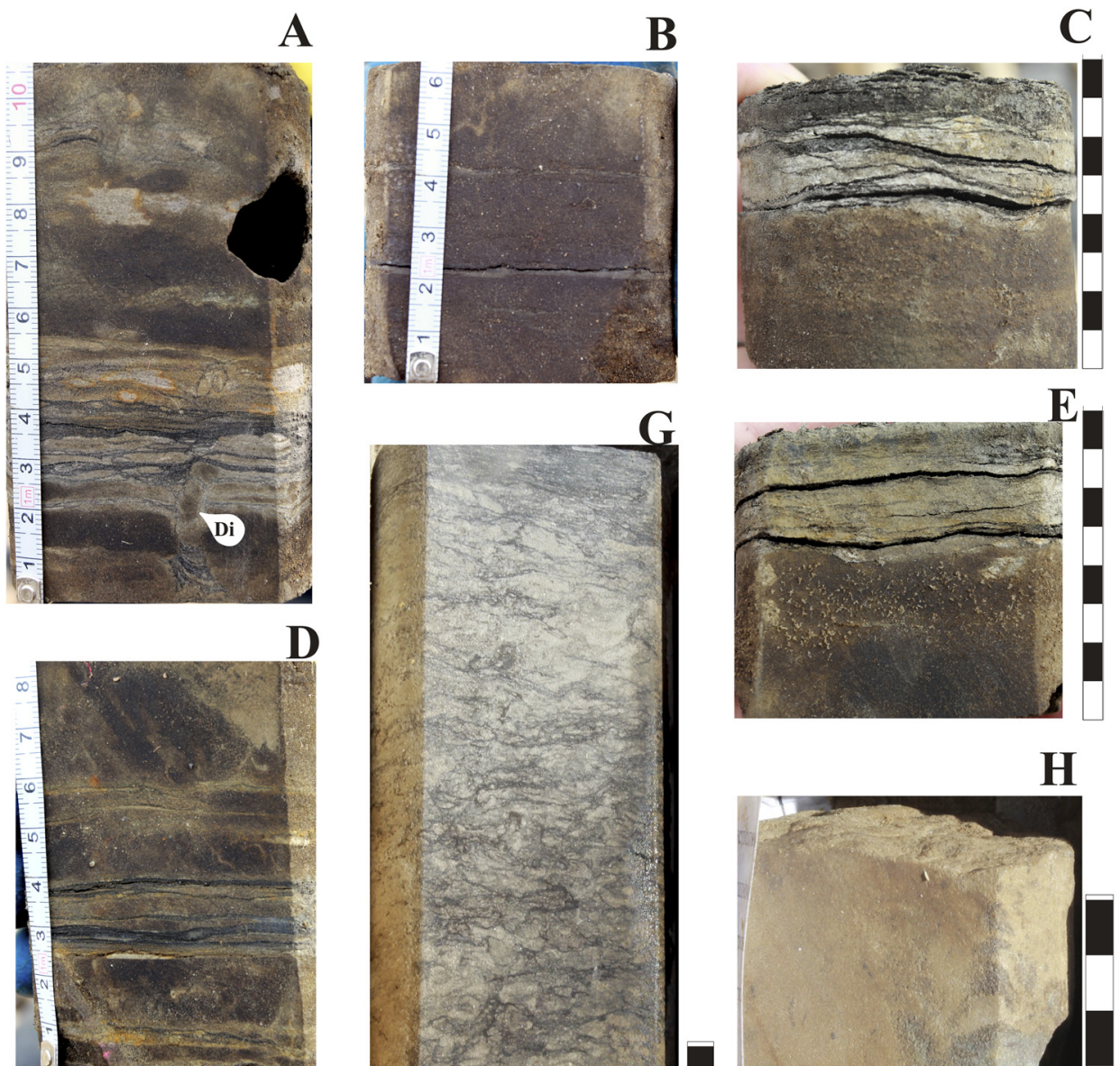

D
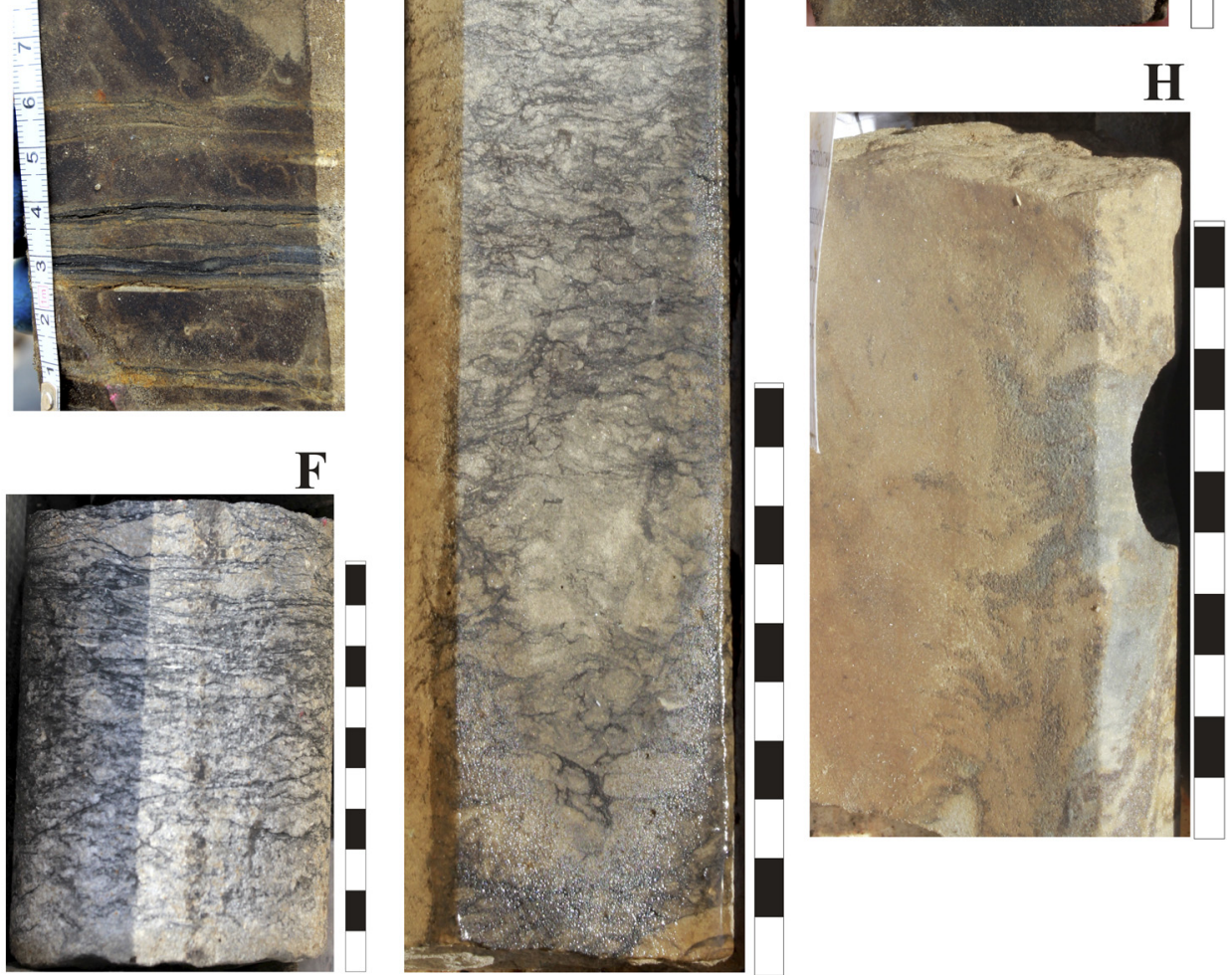

Fig. 8. Sediments of tidal sandflat environment and of transitional sediments to Thulsky shoreface environment. A: Diplocraterion burrows (Di) in medium grained silty sandstone. B-E: wavy laminated thin coal interbeds in fine to medium sandstone. F-H: strongly bioturbated calcareous silty sandstone, transition to Thula carbonate beds (scale bar is in centimeters)

sandy units at the top of Bobrikovsky horizon and overlain by black limestone with remnants of syringopora. Possibly it means a transition to Tulsky carbonates and implies a shoreface facies, or carbonate sand shoal - barrier reefforming period resulted from drowning of the barrier island due to marine transgression.

\section{Distributary channel/Tidal channel facies:}

Weakly cemented light brown, fine to medium-grained massive sandstone (FMs) interrupted by mudstone and claystone interbeds and contains pyrite nodules at a centimeter scale. These sediments were deposited with an erosional base and the occurrence of erosional surfaces is also characteristic. The erosional base is inferred by abrupt change in grain size. Contorted bedding and convolute structure were observed close to the bottom of the beds. It is interpreted as distributary channel fill, or river flood deposit, similar to tidal bores. These sediments are mostly underlain by a small-scale, low-angle heterolithic cross-stratification with mud drapes and reactivation surfaces which indicate 
bidirectional tidal currents in a channelized environment. These subunits are believed to be interflood deposits. The sedimentation of sandstone was interrupted by silty, wavy laminated parts, which contain flame and load structures due to the soft deformation of mud below the overlying dense sandstone layer. The deformation of flame structure is a good signal of the direction of paleo-flow based on the dragging action. Silty rip-up clasts and flute casts confirm the high-energy conditions of fluid flow (Fig. 9/A and B). The thickness of the dark grey mudstone interbeds ranges from $1-2 \mathrm{~cm}$ to $18-20 \mathrm{~cm}$, sometimes exhibiting conchoidal fractures. Coalified wood fragments and interbeds are also recognizable in the subunit which proves the nearshore deposition with fluctuating water depth. The bioturbation is subordinate and concentrated in the silty beds which indicates stressed, brackish conditions or marine influence. Parallel lamination is present sporadically.

Sinusichnus-like trace fossils were generated by decapods or arthropods (Fig. 9/D and E). Sinusichnus was recorded from Ordovician age by Knaust and Descrochers (2019) and from the Lower Carboniferous Mobarak Formation, Iran (Nasiri et al., 2020). Previously it had been known only since
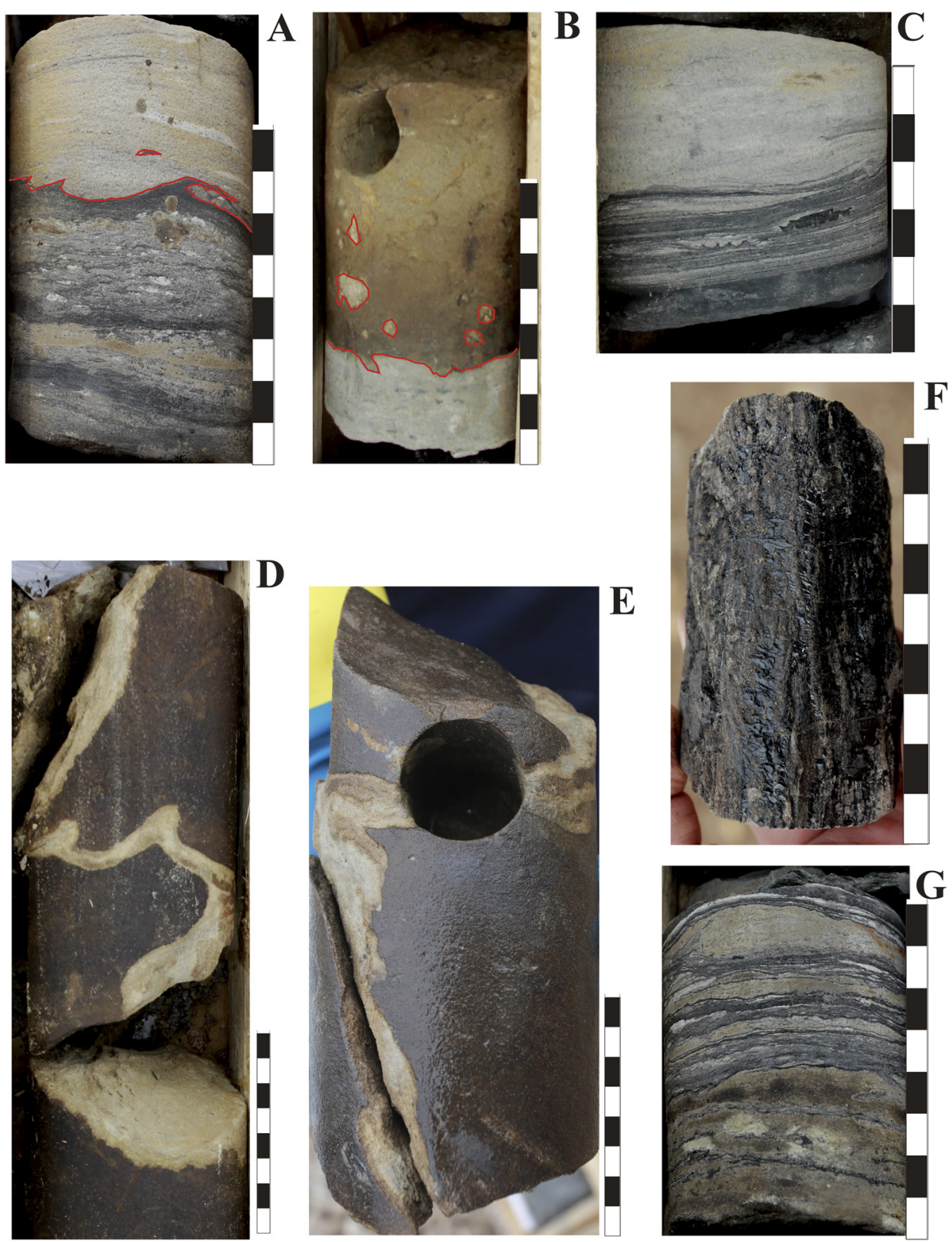

Fig. 9. Sedimentary structures of channel and natural levee environments. A: flame structures and silty rip-up clasts (marked with red) in fine to medium-grained channel sandstone in the middle part and reworked, bioturbated flasered sandy siltstone deposited in upper flow regime below. B: Flute casts and silty intraclasts (marked with red) in almost structureless medium to coarse-grained channel sandstone. C: planar and wavy lamination of fine to medium-grained sandstone in channel fills. D-E: Sinusichnus- like burrows in structureless, massive sandstone of abandoned channel fill. F: coalified, well preserved plant fragments in natural levee environment. G: planar and wavy lamination of medium to coarse grained sandstone with coaly siltstone interbeds and bioturbation (scale bar is in centimeters) 

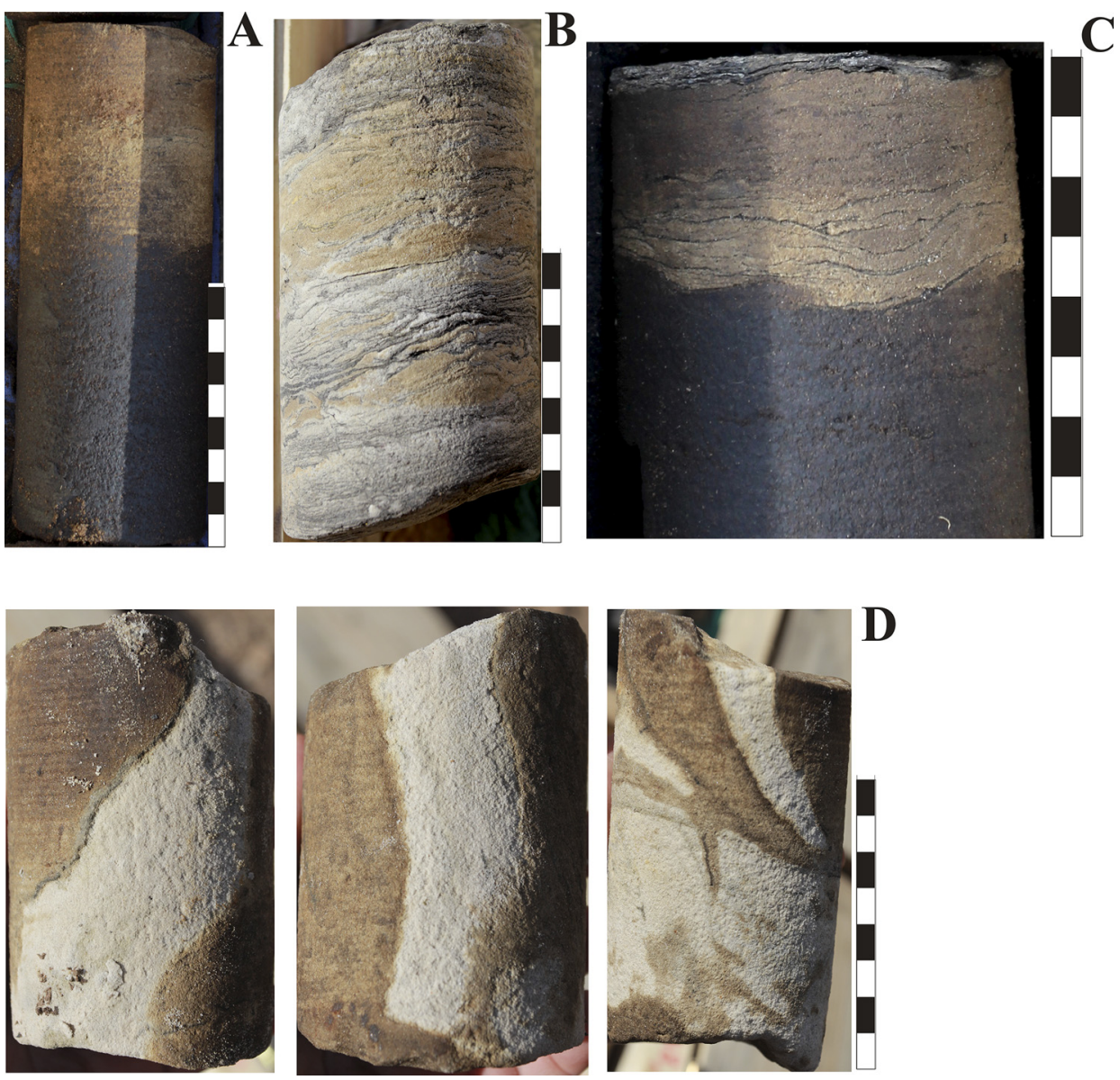

Fig. 10. Sedimentary structures of distributary mouth bar sediments A: Coarse-grained, poorly cemented massive sandstone. The lower part is oil saturated. B: Bioturbated, wavy laminated dolomitic mudstone and medium-grained sandstone C: Relict of hummocky cross-stratification above oil-saturated massive sandstone. Thin coal interbeds on the top. D: Thalassinoides burrows in massive sandstone

the Triassic. According to Buatois et al. (2009) Sinusichnus is known from a wide range of shallow and deep-marine environments, including stressed ones. Horizontally bedded silty, medium to coarse-grained sandstone with coaly silt interbeds with pyrite and anhydrite nodules or nests and high organic detritus content point to sediments of the tidal channel levee environment (Fig. 9/G). Coalified plant fragments are also common (Fig. 9/F). The dark grey or black mudstone (Ssm) sometimes exhibits laminar fractures and wavy lamination. The transition toward the underlying sediments of Bobrikovsky is gradual.

Lithofacies $S m \boldsymbol{c}$ is a coarse-grained, brownish colored, very poorly cemented massive sandstone, occasionally consisting of calcareous sandstone interbeds and wavy laminated, thin coaly layers, or it grades to coarse sandstone with calcareous matrix. The sandstone consists of discrete mud drapes and sporadically of anhydrite nodules. In some cases, in the top region of massive sandstone, relict hummocky cross-stratification can be seen. Due to the strong oil saturation the sedimentary structures were difficult to observe. In Well-12, possible Thalassinoides burrow fill was found in the upper part of the massive sandstone with calcareous sandstone burrow fill as a result of deposit feeding and diagenesis (Jin et al., 2012). These are interpreted as distributary mouth bar deposits (Fig. 10).

\section{STRATIGRAPHY AND FACIES GROUPS FROM WELL LOG CORRELATIONS}

Following the discussion of the core data in the previous section, a larger-scale stratigraphic and facies model is presented based on well log patterns in this section. A synthesis of the proposed depositional model will be the conclusion of this study in the next section, in 'Discussion and summary'.

The lower boundary of the Bobrikovsky Formation is clearly identifiable on well logs in all wells: it is the top Tournaisian unconformity. Well-log trends systematically show an upward-fining trend in the lower half of the Bobrikovsky. The top of that upward-fining trend is the red line in Fig. 11, which represents the maximum transgression or maximum flooding surface. Later, the transgression turned to regression: the upper part of the Bobrikovsky is interpreted to be a highstand regressive systems tract. Based on this observation, the Bobrikovsky is proposed to be divided into two parts: a lower transgressive unit and an 


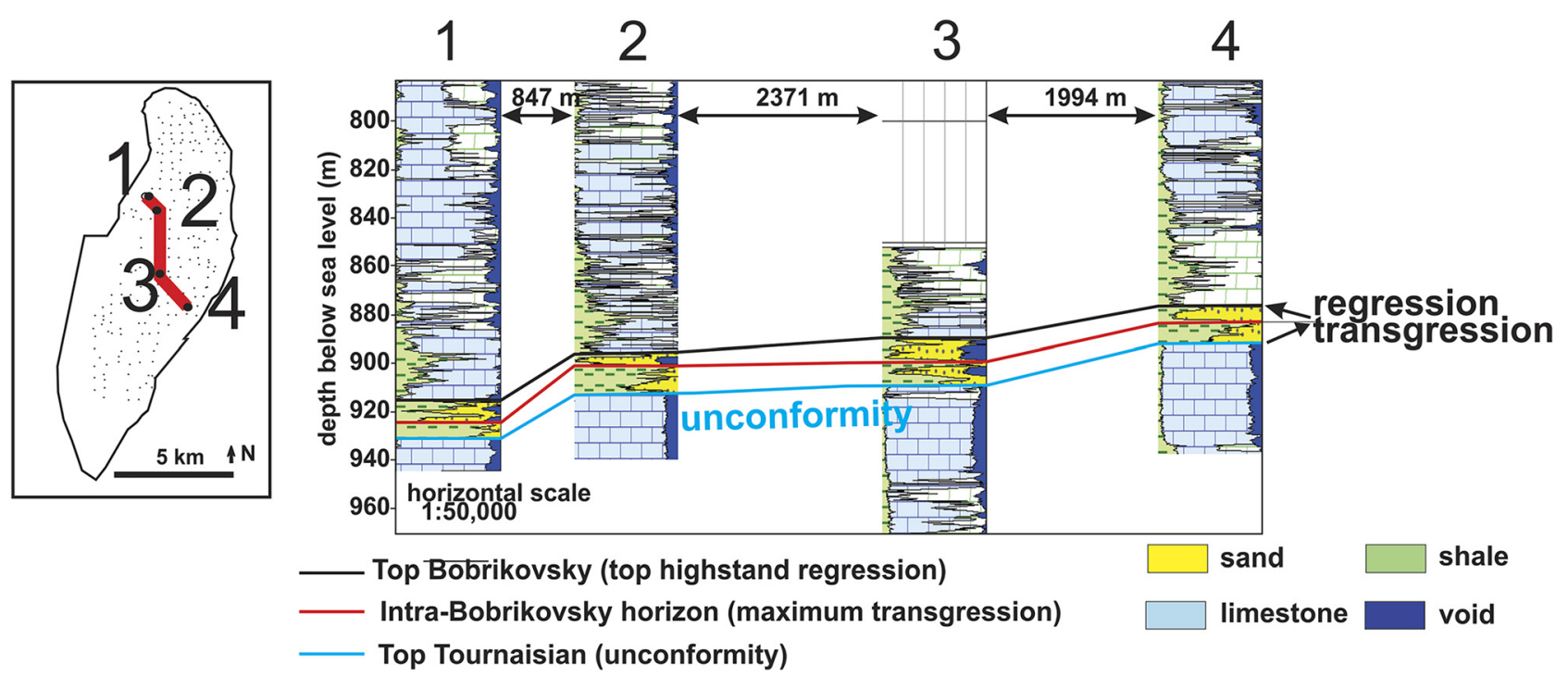

Fig. 11. Proposed stratigraphic framework of the Bobrikovsky Formation

upper regressive unit separated by a maximum transgressive surface. The upper unit tends to be sandier, yet the lower unit also includes sandy facies locally. The separating surface between the lower transgressive and upper regressive unit is called in this study the Intra-Bobrikovsky Horizon. Using sequence stratigraphic terminology (Wilgus et al., 1988; Posamentier and Allen, 1999; Catuneanu, 2006; Catuneanu et al., 2011), the Bobrikovsky Formation is a half sequence, representing a half cycle of relative sea-level excursion, including a lower transgressive and an upper highstand systems tract. It is likely that following the Lower Visean, sea level fell and led to regressive and later normal regressive sediments deposited in the deep parts of the basin, off of our study area. As the sea level rose and reached its peak and a stillstand was established, the carbonate factory resumed on the elevated structure of the study area and highstand carbonates were deposited above the Bobrikovsky Formation. Carbonate platform sedimentation both preceded and followed the Bobrikovsky Formation; it was a siliciclastic episode, an interruption in a long series of carbonate production. The interruption was caused by a sea-level fall and subsequent rise that temporarily switched off the carbonates in the Lower Visean.

Facies were defined on well log patterns in the above stratigraphic framework, separately for the transgressive and highstand systems tracts. Six facies or facies groups have been defined in the study area where the production wells are located; three of them are below the Intra- Bobrikovsky Horizon in the transgressive systems tract, and three are in the upper regressive unit. These facies are presented in the next sub-sections. More facies were defined beyond the field area based on seismic data.

As the core data gave evidence presented in the previous section of the paper, the overall depositional environment is a nearshore-coastal zone, which is located in the broad shallow shelf of the Volga-Urals Basin. Barrier islands were deposited that enclosed lagoons and estuaries. Tidal deltas, including flood tidal and ebb tidal deltas and tidal channels were deposited in and in front of the lagoonal series. First, the three facies below the Intra- Bobrikovsky Horizon, and then the other three facies above the horizon will be discussed.

\section{FACIES IN THE LOWER TRANSGRESSIVE SYSTEMS TRACT}

\section{Lagoon-estuary, and transgressive barrier bar facies groups}

A characteristically silty-shaly and upward fining trend is interpreted as a lagoon or estuary deposit (Fig. 12).

Transgressive barrier islands (Hayes, 1996) do not have a unique grainsize trend; it can be constant on average or may contain thin, slightly upward-fining parasequences (Van Wagoner et al.,1990) or T cycles of Zecchin (2007). Published key lithological columns correspond with our observations (Reinson, 1992) (Fig. 12). If there is a washover fan on the top, the grainsize trend is upward-coarsening; if there is no washover, the trend is more upward- fining. The overall stratal architecture of transgressive barrier islands is retrogradational or backstepping, in correspondence with the geometry of transgressive systems tracts in general (Zecchin et al., 2019). Some transgressive lag deposit may accumulate at the toe of the island. As the island migrates landward, the lagoon eventually becomes filled while the seaward side of the island is subject to erosion.

Ebb tidal and flood tide deltas are essential parts of the depositional system in tidal environments, and probably were major processes of sand deposition in our study area during both the transgressive and highstand phases. Ebb tidal deltas form in front of inlets by low tides. They usually contain large amounts of sand. Modern examples were shown from South Carolina by Sexton and Hayes 


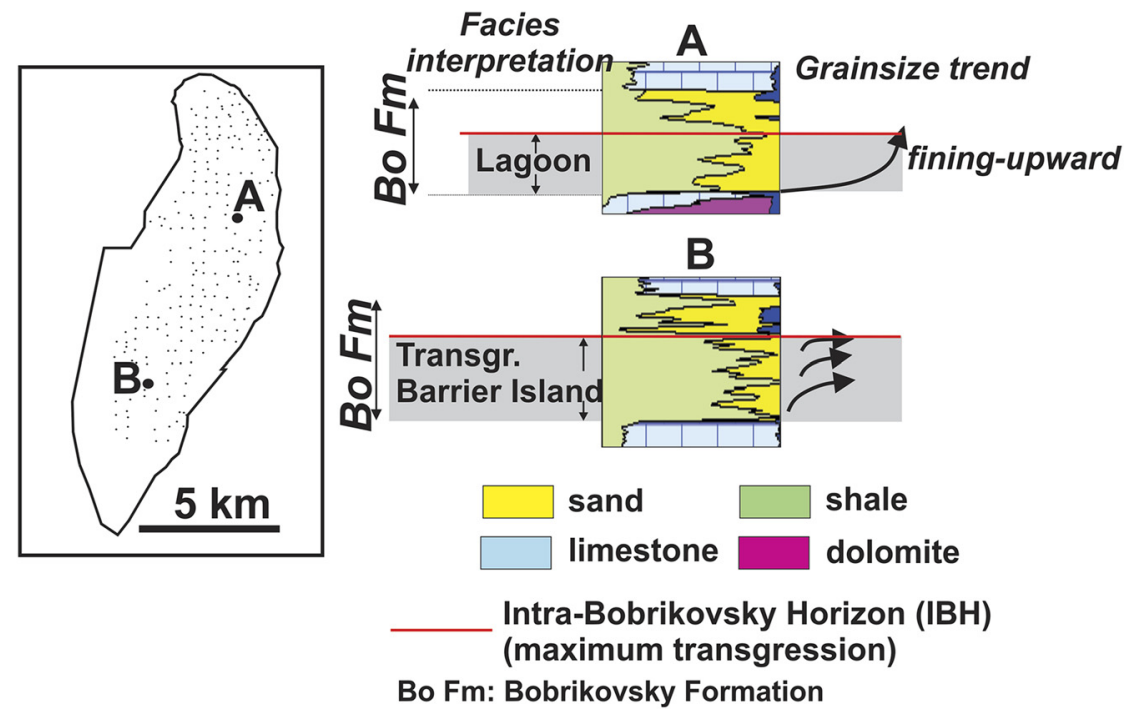

Fig. 12. Well log examples for the lagoon-estuary (well A) and the transgressive barrier island (well B) facies group in the lower transgressive systems tract

(1996) that may be used as an analogy. Ebb-tidal deltas with ebb channel, terminal lobe, swash bars and marginal flood channels are the main constituents of the depositional system. Flood tidal deltas accumulate in the lagoon by high tides. The preservation potential of the flood-tidal delta is better than that of the ebb-tidal delta, because it accumulates in a sheltered environment. The ebb-tidal delta can be reworked more easily by longshore currents and waves. It is likely that a large part of the tidal sands in our study area (lower unit) is of flood tidal delta and tidal channel origin.

\section{Tidal channel group}

Sand content increases in tidal channels and the log pattern is blockier and upward-fining. These channels occur in inlets and connect the tidal deltas between the lagoon and inlets (Fig. 13).

\section{FACIES IN THE UPPER HIGHSTAND SYSTEMS TRACT}

\section{Lagoon fill series and prograding barrier islands}

As the sea level became stabilized and the sediment supply increased, the transgression turned to regression and highstand normal regressive conditions reigned. The lagoon system was filled with silty and sandy sediments (Fig. 14) by flood tidal deltas and also by fluvial input.

Former transgressive barrier bars became regressive, or progradational (Hayes, 1996) and built toward the sea (Fig. 14). They also merged with the lagoon fill material and altogether constituted parts of a newly forming lower coastal plain. The former barrier-lagoon system became a strandplain. The grainsize trend is a characteristic upward-coarsening one, in correspondence with key published columns

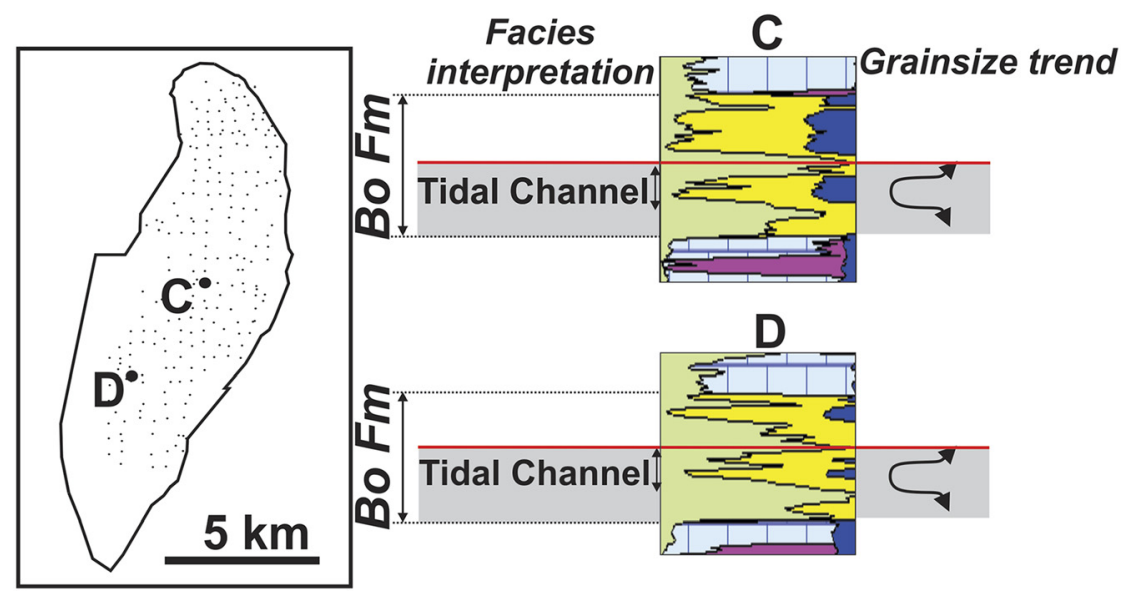

Fig. 13. Well log examples of tidal channel facies 

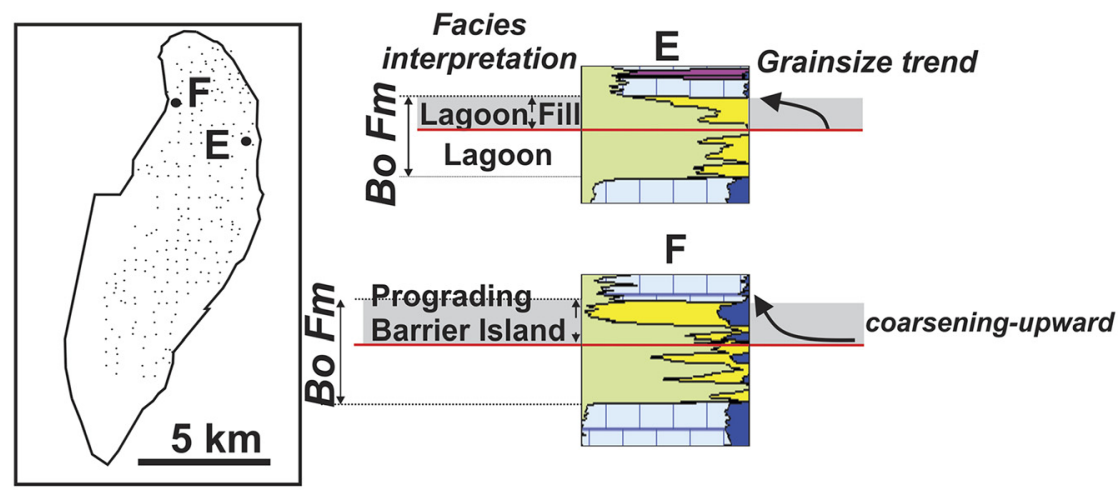

Fig. 14. Well log examples of regressive lagoon-fill facies group (Well E) and prograding barrier island group (Well F)

(Reinson, 1992). The facies system may include local mouth bars and upper shoreface as well.

\section{Tidal-Fluvial channels}

Former tidal channels are interpreted to have become more fluvially influenced as the continental sediment supply increased in the regressive stage. These features are essentially the same distributaries as identified in the tidal channel facies (Fig. 13); their log patterns are also similar (Fig. 15). The same physical channels were conduits of both tidal currents and fluvial fresh water flow; the two currents were mixed according to daily tidal cycles. The fluvial dominance is believed to have slightly increased in the regressive stage of the Bobrikovsky deposition.

\section{Facies maps from correlations of well log patterns}

Our stratigraphic framework included a lower transgressive and an upper highstand regressive systems tract. The transgressive unit included lagoon-estuary series and transgressive barrier bars. As the transgression culminated and regression took over, the lagoons were filled with tidal bars and the barrier islands became progradational. Well-log correlations on over 300 wells made a high-resolution interpretation possible. Two facies maps were constructed; one for the lower transgressive (Fig. 16A) and another for the upper regressive phase (Fig. 16B). Seismic data also revealed a meandering channel at the northern area. It is a transitional fluvial-tidal channel according to our interpretation. The character of the channel is more fluvially influenced westward, and it gradually becomes the pathway for tidal currents eastward. The channel ends with an estuary in the east. The estuary probably was filled up by bayhead deltaic deposits in the regressive phase. The deposits circled by the meanders are point bars, being also mixed under both fluvial and tidal currents. Reviewing analogs may be a powerful way to predict possible facies distributions or verify interpretations. Elongated tidal bars are typically present in the funnel-shaped estuary, oriented perpendicular to the coastline. Mudflats are located at the edges of the estuary and salt marshes surround the river channel (Dalrymple and Choi, 2007).

\section{DISCUSSIONS}

Sandstones of the Bobrikovsky unit in the Orenburg region including relatively narrow, long strips have been reported
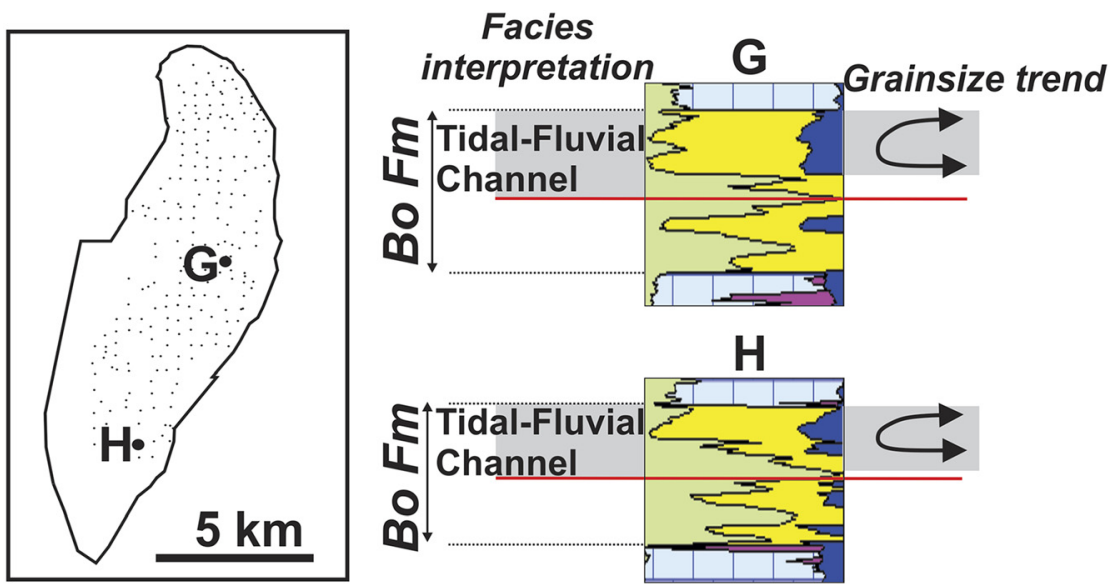

Fig. 15. Well log examples of tidal-fluvial channels in the upper highstand systems tract. Mostly, these channels were tidal creeks in the former transgressive systems tract that became more fluvially influenced in the regressive phase 


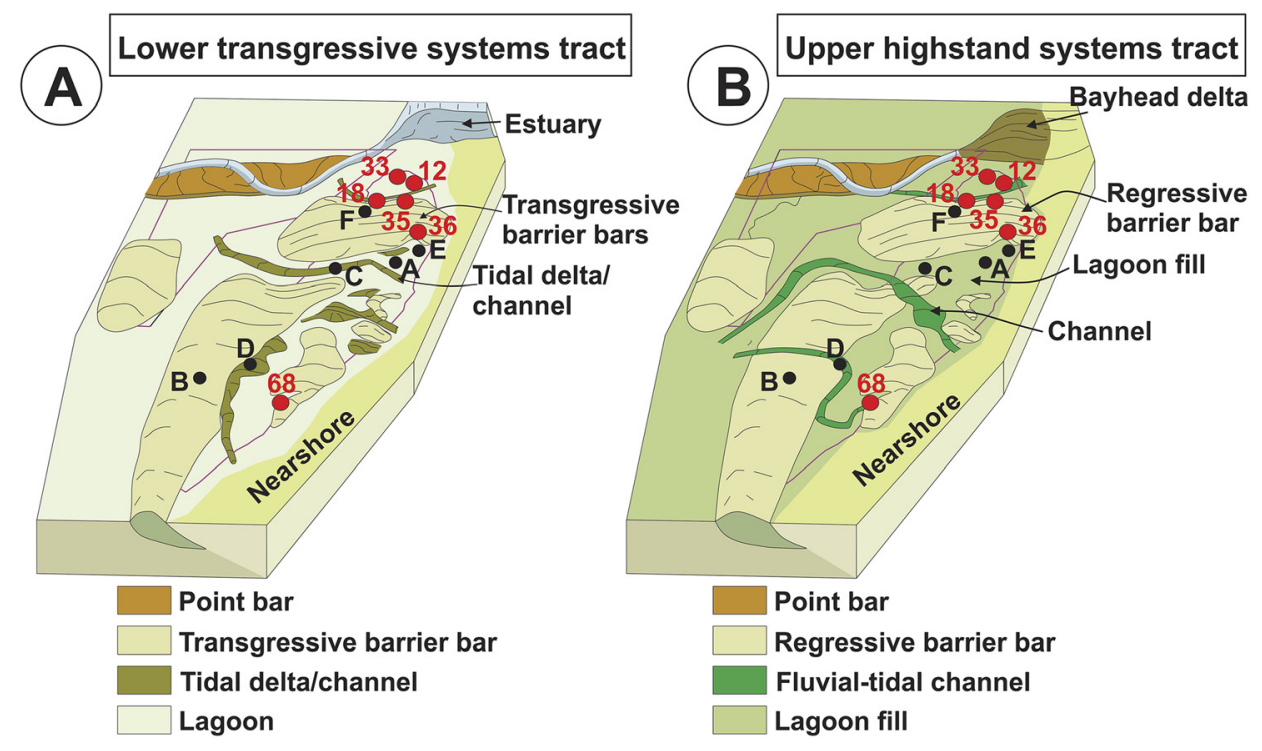

Fig. 16. A: Block diagram of the facies map constructed for the lower transgressive systems tract. Lagoons and transgressive barrier islands and tidal deltas were dominant in the study area. Black dots are locations of the wells used as examples at well log facies definitions in Figs 12-15. Red discs are locations of wells with core samples (see Figs 17 and 18). B: Block diagram of the facies map constructed for the upper highstand systems tract. The lagoons filled up the barrier islands became progradational. The lower coastal plain extended eastward. Black dots are locations of the wells used as examples for well log facies definitions in Figs 12-15. Red discs are locations of wells with core samples (see Figs 17 and 18)

from borehole data since the 1960s (Markovskiy, 1973). Similar lithological features to those observed in our study area were recognized by Kulanov et al. (1962); the sediments were considered probable ancient debris flows or microdelta sediments. According to their investigation, the sandstone content in the Bobrikovsky Formation was variable: sand was predominant in its upper part, directly under the overlying limestones, while the amount of sand was less in the middle part where it interfingered with mudstones. In some places, there were two sandy layers in the upper part. These observations are consistent with our finding that the upper Bobrikovsky is sand-rich, being the product of a marine regression.

ONAKO (1997) also reported a transgression at the end of the Tournaisian and beginning of the Visean, while a regression was prevalent on the Russian Platform. In the Orenburg region, the Bobrikovsky was deposited in a shallow-water shelf zone, but it was emphasized that in the northern part of the region - where our study area is located - coastal marine conditions existed, which corresponds with our interpretations.

The Visean clastic section of Volga-Ural Region is mentioned as an analog to Chesterian sandstone section of the north-central United States in Peterson and Clarke (1983). Chesterian sandstone was deposited in a deltaic and nearshore marine environment; sandstone bodies show lensing and a sinuate nature interbedded with dark marine shale facies. Source areas for the Visean clastic and the Chesterian sandstones are compared; both cases involve reworking and redeposition of previously deposited sands by streams flowing off the margins of a cratonic continental mass into an advancing marine seaway (Peterson and Clarke, 1983).
Nelson et al. (2002), referring to Dalrymple et al. (1994) and Zaitlin et al. (1994a, 1994b), describe the Lower Chesterian (Mississippian) strata of the Illinois Basin as an incised valley fill which typically contains coarse fluvial sandstone in the lower part, overlain by finer-grained rocks that show increasing tidal influence upward. This type of trend is missing from the Bobrikovsky sequence of Field-A. Chesterian (Upper Mississippian) incised valley fills of the Hugoton Embayment of southwestern Kansas was investigated by Senior and Walton (2011) and the facies is described as conglomerate, pebbly sandstone, laminated sandstone, and cross-bedded sandstone. Previous studies of the paleovalley indicate deposition in a tide-influenced estuarine system. In Bobrikovsky deposits of Field A the conglomerate and pebbly sandstone as a marker of typical lag deposits are also absent.

The depositional environment of the Carboniferous sandstone reservoir of Romashkinskoye oil field - which is a giant field in the Volga-Ural region with similar geologic setting and reservoirs - was determined to have been a deltaplain distributary channel by Lu et al. (2013).

The coastal - marginal marine origin of the Bobrikovsky unit in the region was verified by Astarkin et al. (2013). This study emphasized the variable structure and appearance of Bobrikovsky sediments, which were deposited in a transitional zone from land to sea with a predominance of coastal marine sedimentary environments. The spatial distribution of the sediments is sometimes relatively whimsical. The study emphasized that Bobrikovsky deposits are associated with short-term, frequently changing transgressive-regressive movements; cyclic flooding, as a result of which coastalmarine terrigenous deposits were accumulated on the 
denudated surface of the Famennian-Tournaisian carbonate platform. The ichnogenera which were written down are also similar to Bobrikovsky of Field A.

The spatial distribution and heterogeneity of Visean sediments of the Volga-Ural Petroleum Province was also investigated by Peterson and Clarke (1983b). It was found that an intricate network of early Visean stream channel sandstones was widespread in the region which completely filled the Kamsko-Kinel trough system. These stream channel sandstones change to nearshore-marine and deltaic deposits in the upper part of the sequence and become interbedded with transgressive marine shale. The middle Visean contains marine sandstone intervals which are indicative of minor cyclic shoreline fluctuations.

In this context the current study's results and insights are in good correspondence with the mentioned studies.

\section{SUMMARY OF THE RESULTS}

In our study, well log interpretations and correlations were employed that resulted in the formulation of a stratigraphic framework and identification of large-scale facies groups on well log trends and patterns. Sedimentological investigation of cores provided detailed information on lithofacies and depositional environments and established the understanding of the main sedimentary systems. The Bobrikovsky Formation is proposed to be divided stratigraphically into two main parts, a lower transgressive and an upper highstand systems tract. Mainly estuaries/lagoons, tidal deltas and transgressive barrier islands were deposited in the transgressive phase, while lagoon fills and prograding barrier islands were dominant in the upper normal regression. Tidal channels were also identified on well logs that were under both tidal and fluvial influence. The core lithofacies Mlp, Msb, Smw are parts of the lower transgressive systems tract and Ssb, Mlp, Msb, Smc, Scr, Ssm are facies in the upper regressive stage. This linkage between lithofacies and well log pattern is the bridge to achieve a viable understanding.

This process is clearly seen by the evaluation of sedimentary architecture of Well 33 and Well 12 (Fig. 17). In the transgressive phase both of their surroundings belonged to an estuarine-lagoonal environment with neighboring coastal marsh territories. After the culmination of transgressive phase, the lagoonal area started to fill with increasingly sandy deposits, and fluvial processes took command instead of tidal influence. The location of Well 33 and Well 12 began to fill with the sediments of the prograding distributary mouth bar of the channel, which settled onto the top of tidal flat and lagoonal deposits as bayhead delta deposits. Well 35 in the transgressive phase was located at a coastal lagoonal position, close to the coastline, where estuarine, tidal flat, marshy and lagoonal environments replaced each other accordingly to the actual sea-level fluctuations. In the regression phase a natural levee started to build with high organic detritus content and coalified plant fragments in coal interbeds. The thickening of sandy deposits, signs of dragging fluid flow in the upper flow regime, muddy rip-up clast and contorted bedding at the base proves the channelized flow sedimentation. In Well 35 the depositional history is very similar, and the existence of a channel is more pronounced by cores and coastal position is proved by coalified wood fragments and pieces (Fig. 17).

In Well 18 the lower part of the transgressive phase was not cored; thus, only well logs and the drilling report helped to identify the depositional environment, which is presumably lagoonal. Upper sandy units of Well 18 and Well 36 demonstrate the regressive barrier island stage in the northern part of Field A (Fig. 18). In the regressive phase a bay mouth bar or a barrier bar started to form, just as in the area of Well 36. In the latter well, the forming of a barrier bar in the transgressive phase is more obvious from the washover sediments deposited on coastal swamp sediments (Fig. 18). Well 68 is situated south of the wells mentioned above. The lower part of the sequence is not known from
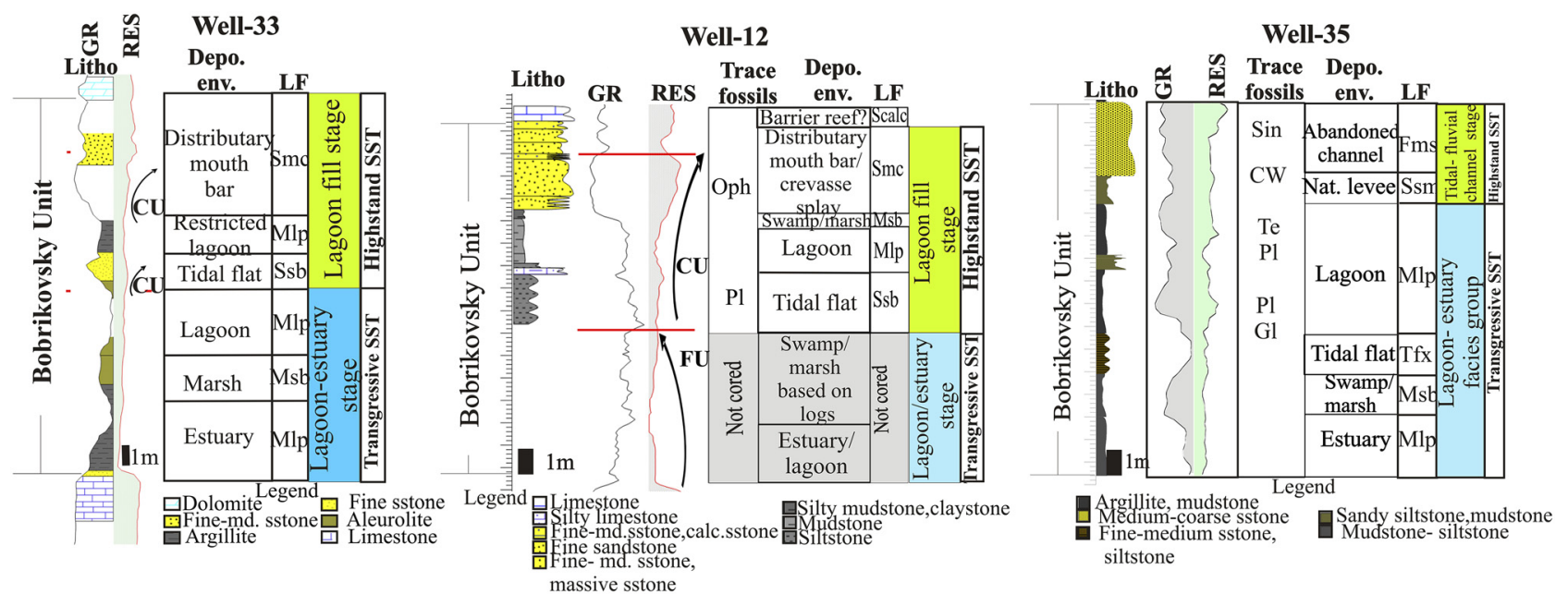

Fig. 17. Depositional environments of the Bobrikovsky unit in key wells No. 33, No. 12 and No. 35 in the transgressive and highstand system tracts based on GR and RES logs and cores. See Fig. 16 (red discs) for locations of wells 

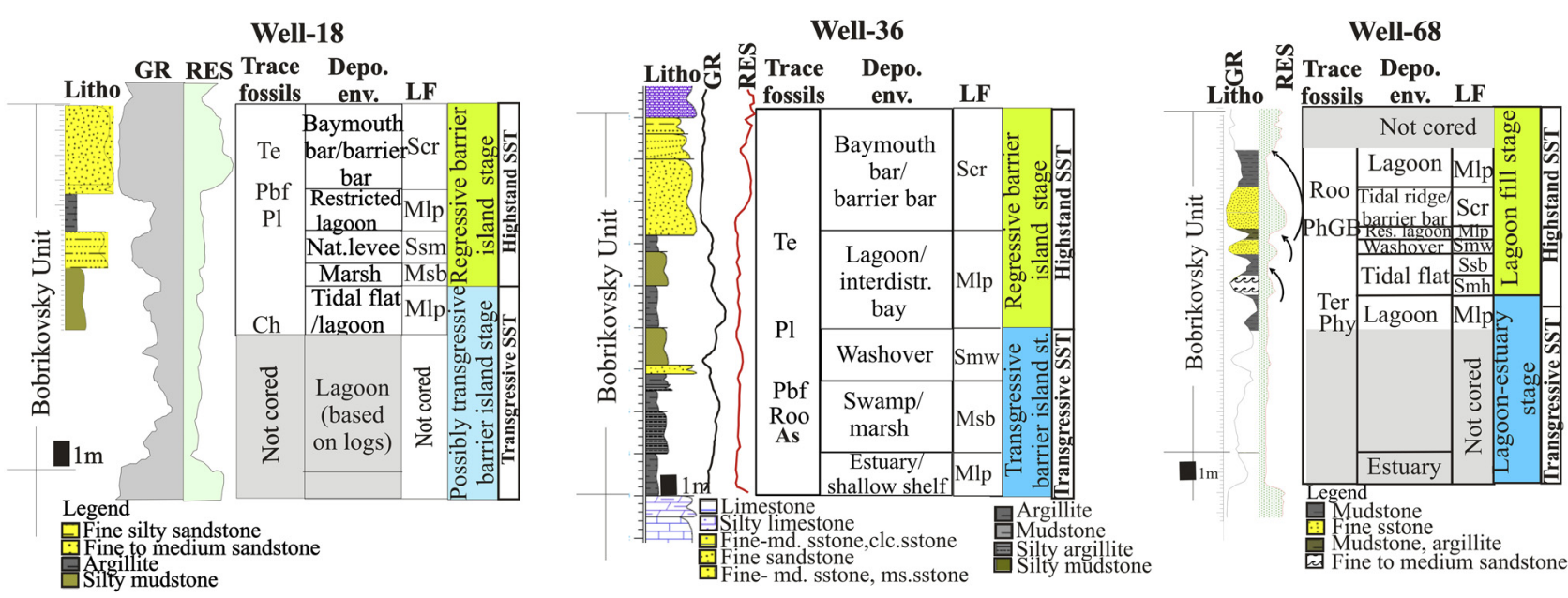

Fig. 18. Depositional environments of the Bobrikovsky unit in key wells No. 18, No. 36 and No. 68 in the transgressive and highstand system tracts based on GR and RES logs and cores. See Fig. 16 (red discs) for locations of wells

core. According to log motifs and the basic description of the drilling report, a possible estuary-shallow shelf environment is presumed (Fig. 18). In the regressive barrier island stage, sandier tidal flat sediments changed the lagoonal deposits. Washover sands in relatively small thickness were recognized from cores. The vicinity of Well 68 was possibly blocked from marine influences and became a restricted lagoonal area, then a tidal sand ridge-forming period started, when fine to coarse-grained sandstone was deposited with iron oxide stains, root traces and thin coal drapes. These sandstone series are overlaid by the sediments of lagoonal and marshy deposits.

Focusing on the well logs, careful attention was required to correlate each log motif, owing to the relatively heterogenous spatial distribution of sandy interbeds of the Bobrikovsky unit. Comparatively reliable lithological pattern and depositional environments had been set up, verified by core description where available. Beginning from the neighborhood of the six key wells, the sedimentary structure, which was discussed above, was confirmed, as well as the depositional environments based on sedimentary core description. In Fig. 19 the channel-point bar sequence and the lagoon-barrier bar sequence can be tracked and checked in time and space.

\section{CONCLUSION- IMPLICATIONS FOR HYDROCARBON DEVELOPMENT}

Core sedimentology and well log facies complemented each other efficiently and allowed building a comprehensive depositional model. During the Bobrikovsky age a bayhead delta-lagoon-estuary-back barrier complex was formed, supplemented by extended floodplains or tidal mudflats and mixed sand-mudflats. The channels and distributary channels were narrow, coupled with shallow water depth, and were often abandoned and filled.

The sediment supply from the coastal area was limited, but peat and coal-forming environments were common. The area was surrounded by mangrove-like flora, which is confirmed by coalified, well-preserved plant fragments. The tranquil sedimentation of the back barrier-beach environment in semi-arid climate was influenced by occasional storm and/or tide-driven processes. Thin carbonaceous laminae and cement also prove several marine flooding events. The direction of sedimentation is NW-SE. Field A was located in a marginal marine area with a northwest-west shifting coastline while the area ESE of Field A was occupied by the marine basin.

The Bobrikovsky Formation is both vertically and horizontally extremely heterogeneous in the area of interest; hence making the reservoir development very challenging and risky. (E.g.: There are wells with several tens of meters of net pay, and a few hundreds of meters away, wells with zero meters of net pay). The predictability of good reservoir rocks (a.k.a. sand bodies) is very poor if based solely on geostatistical methods. It was necessary to gain insight in order to drive the spatial understanding and modeling of the reservoir. The net-to-gross ratio is around $25 \%$. In order to be able to make an economically sound well pattern to exploit the reservoir it is crucial to understand the sand distribution, since these sand bodies are the targets for development wells and main contributors to production.

The presented core and log-based sedimentological study was performed in order to support the optimization of field development in Field A by increasing the understanding of reservoir distribution.

The facies maps and polygons generated as a $2 \mathrm{D}$ summary of the interpretive work could be directly used in geocellular rock-type modeling as trend inputs for pixelbased, and/or as objects' dimensions in object-based modeling. The incorporation of the gathered understanding into geologic models fosters the accuracy of dynamic models.

The conducted work can have a significant impact on in-fill well locations, the number of in-fill wells, well work- 


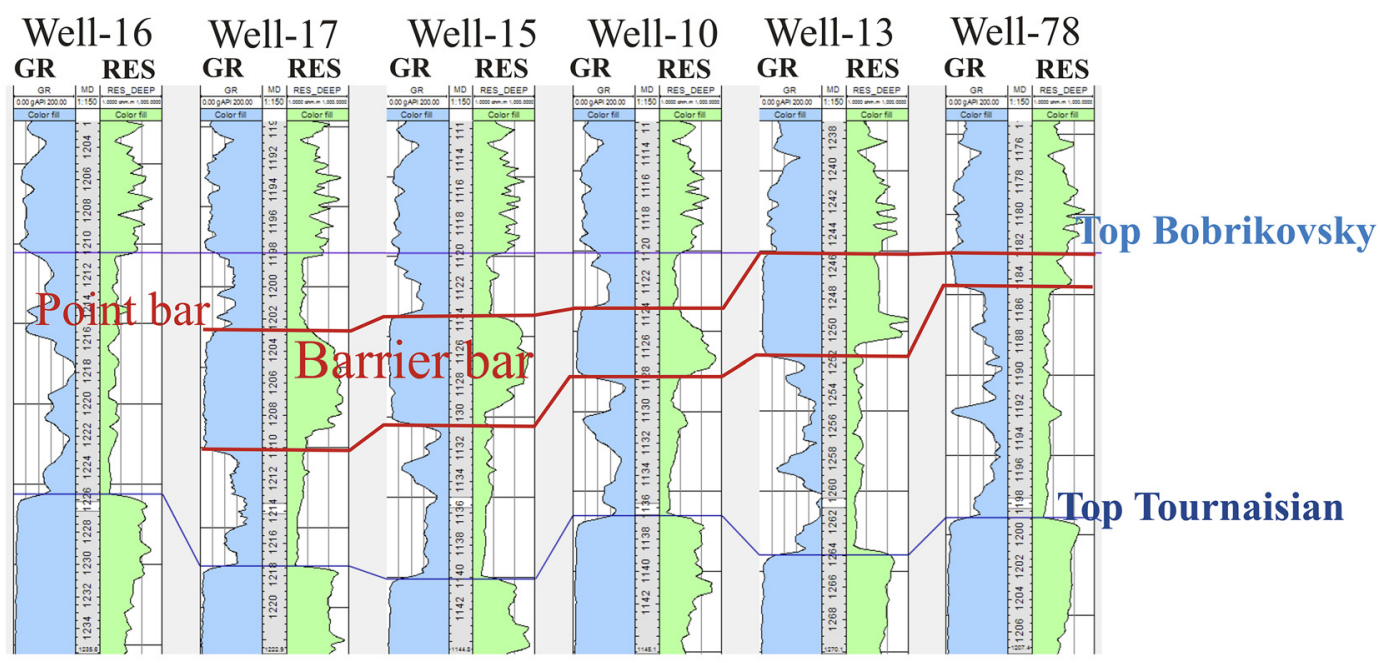

Depth:MD
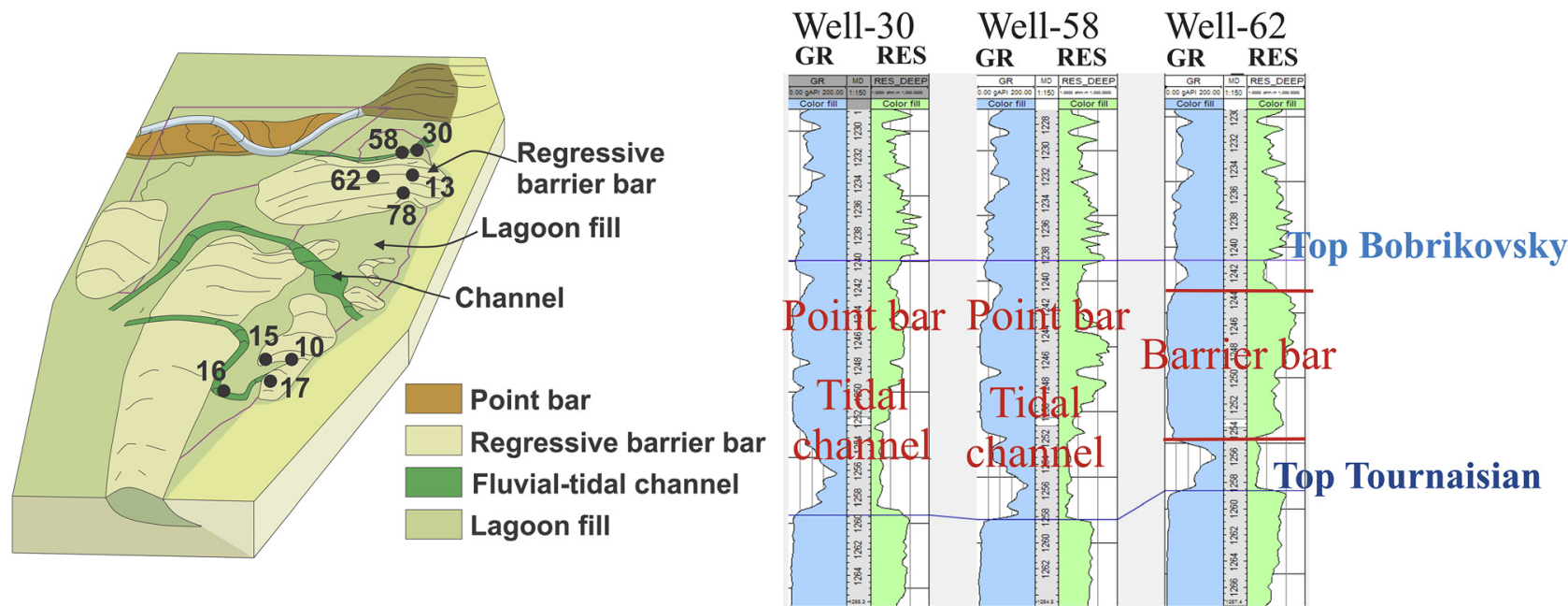

Fig. 19. Channel-point bar sequence and lagoon-barrier bar sequence in space and time in the Bobrikovsky unit of Field-A in the vicinity of key wells based on GR and RES logs

overs, production and injection strategy, eventually on hydrocarbon production and net present value of the reservoir.

Similar studies can transform a secondary or tertiary drilling target into a primary target with untapped potential, significantly improving the finding and production costs via increasing the success rate in drilling by-passed locations even in a very mature hydrocarbon field.

\section{ACKNOWLEDGEMENTS}

The authors are grateful to MOL Plc. for supporting this research and would like to thank Russian colleagues at the site, every colleague in the office and laboratory for professional and technical support. Helpful suggestions and critical comments of reviewers and readers are always welcome and acknowledged.

\section{LIST OF ABBREVIATIONS}

$\begin{array}{ll}\text { As } & \text { Asteriacites lumbricallis } \\ \text { Ch } & \text { Chondrites } \\ \text { CU } & \text { coarsening upward cycle } \\ \text { Cw } & \text { coalified wood fragments } \\ \text { Di } & \text { Diplocraterion } \\ \text { FE } & \text { fluid escape structure } \\ \text { FU } & \text { fining upward cycle } \\ \text { Gl } & \text { Glossifungites } \\ \text { GR } & \text { gamma ray } \\ \text { HC } & \text { hydrocarbon } \\ \text { IHS } & \text { IHS Markit database } \\ \text { Lo } & \text { load structure } \\ \text { Md } & \text { mud drapes } \\ \text { md. } & \text { medium } \\ \text { Mr } & \text { mud ripples } \\ \text { NP } & \text { nodular pyrite } \\ \text { Oph } & \text { Ophiomorpha burrows }\end{array}$


Pbf Pyritized burrow fills

PhGB Photosynthetic gas bubbles

Phy Phycosiphon

Py pyritized burrow fill

RES resistivity

$\mathrm{Rh} \quad$ Rhizocorallium

Roo rooting

Sin Sinusichnus-like burrows

Sm scratch marks

Sp spreite

sstone sandstone

Sy syneresis crack

Te Teichichus

Te $r \quad$ Teredolites

Th Thalassinoides

VUB Volga-Urals Basin

\section{REFERENCES}

Astarkin, S.V., Goncharenko, O.P., Sheglov, V.B., Pisarenko, Y.A., and Zotov, A.N. (2013). Litologo- facialnaya haracteristica Bobrikovskih otlozhenniy berezovskoy gruppi mestorozhdenniy (blizhneye Saratovskoe zabolzhe). VII. Vserossiyskoe litologicheskoe soveshanie, Saratov, pp. 1-4.

Bolucek, C. and Ilhan, B. (2006). A survey of pyritised animal, plant, and trace fossils and concretionary pyrites, Germav Formation, southeastern Turkey. Comptes Rendus Geoscience, 338(3): 161-171, Elsevier.

Bromley, R.G. and Ekdale, A.A. (1984). "Chondrites": a trace fossil indicator of anoxia in sediments. Science, 224(4651): 872-874.

Buatois, L.A., Gingras, M.K., Maceachern, J., Mangano, M.G., Zonneveld, J.P., Pemberton, S.G., Netto, R.G., and Martin, A. (2005). Colonization of Brackish-water systems through time: evidence from the trace-fossil record. Research Report, $P A L-$ AIOS, 20: 321-347.

Buatois, L.A., Macsotay, O., and Quiroz, L.I. (2009). Sinusichnus, a trace fossil from Antarctica and Venezuela: expanding the dataset of crustacean burrows. Lethaia, 42: 511-518.

Catuneanu, O. (2006). Principles of sequence stratigraphy. Elsevier, Amsterdam, p. 375.

Catuneanu, O., Galloway, W.E., Kendall, C.G., Miall, A.D., Posamentier, H.W., Strasser, A., and Tucker, M.E. (2011). Sequence stratigraphy: methodology and nomenclature. Newsletters Stratigraphy, 44(3): 173-245.

Dalrymple, R.W. and Choi, K. (2007). Morphologic and facies trends through the fluvial-marine transition in tide-dominated depositional systems: a schematic framework for environmental and sequence-stratigraphic interpretation. Earth-Science Reviews, 81: 135-174.

Dalrymple, R.W., Knight, R.J., Zaitlin, B.A., and Middleton, G.V. (1990). Dynamics and facies model of a macrotidal sand-bar complex, Cobequid Bay-Salmon River estuary (Bay of Fundy). Sedimentology, 37: 577-612.

Golov, A.A., Korolyuk, I.K., Melamud, Y.L., Sidorov, A.D., and Punanova, S.A. (2000). Structural-formational characteristics of devonian clastic complex of Volga-Ural Province. Petroleum Geology, 34: 213-222.

Hayes, M.O. (1996). Barrier island basics. Geotimes: 17, December 1996.

Homann, E. (2019). Earliest life on earth: evidence from the Barberton Greenstone Belt, South Africa. Earth-Science Reviews, 196: 13-16, 102888, Elsevier.

Homann, M., Heubeck, C., Airo, A., and Tice, M.M. (2015). Morphological adaptations of $3.22 \mathrm{Ga}$ - old tufted microbial mats to Archean coastal habitats (Moodies Group, Barberton Greenstone Belt, South Africa). Precambrian Research, 266: 5458, Elsevier.

Huvaz, O., Sarikaya, H., and Isik, T. (2007). Petroleum systems and hydrocarbon potential analysis of the northwestern Uralsk basin, NW Kazakhstan, by utilizing 3D basin modeling methods. Marine and Petroleum Geology, 24: 247-275.

Jin, J., Harper, D.A.T., Rasmussen, J.A., and Sheehan, P.M. (2012). Late Ordovician massive- bedded Thalassinoides ichnofacies along the palaeoequator of Laurentia. Palaeogeography, Palaeoclimatology, Palaeoecology, 367-368: 73-88, Elsevier.

Knaust, D. (2017). Atlas of trace fossils in well core: appearance, taxonomy and interpretation. Springer, p. 158 and 74.

Knaust, D. and Desrochers, A. (2019). The trace fossil Sinusichnus from the Upper Ordovician of Anticosti Island, Eastern Canada. Lethaia, 10.111: 1-8.

Kulanov, A.I., Svishev, M.F., and Panteleyev, A.S. (1962). Osobennosti razrabotki nizhnekamennougolnih zalezhey nefti centralnoy chasti Bolshekinelskovo vala. Geologia Nefti I Gaza, 06: 21-27.

Lu, L.L., Zhibin, L., Haohan, L., and Yongqin, Y. (2013). Study on technical measures of Romashkino Oil Field after entering ultra-high water cut stage. Scientific Research, Engineering, 5: 622-628.

Markovskiy, N.I. (1973). Paleogeograficheskiye osnovy poiskov nefti i gaza. Moscow: Nedra, pp. 242.

Meyerhoff, A. (1984a). A Carboniferous oil and gas production in the eastern hemisphere I. Journal of Petroleum Geology, 7(2): 125-146.

Meyerhoff, A (1984b). A Carboniferous oil and gas production in the eastern hemisphere II. Journal of Petroleum Geology, 7(2): 125-146, 7, 3, pp. 313-328.

Nasiri, Y., Bayet-Goll, A., Mahboubi, A., Moussavi-Harami, R., and Monaco, P. (2020). Paleoenvironmental control on tracefossils across a Mississippian carbonate ramp succession, Mobarak Formation, east of Central and Eastern Alborz, Iran. Journal of African Earth Sciences, 165: 1-22, Elsevier.

Nelson, W.J., Smith, L.B., and Treworgy, J.D. (2002). Sequence stratigraphy of the Lower Chesterian (Mississippian) strata of the Illinois Basin. Illinois State Geological Survey, Bulletin, 107: 8 .

Nemes, I., Szilagyi, Sz.S., and Csato, I. (2021). Challenges of a mature Russian field's re-development - advantages and disadvantages of quick-look geological modelling. Central European Geology, in press.

Orenburgskaya Neftyanaya Aktionernaya Kompania (ONAKO). (1997). Geologicheskoe stroenie i neftegazonocnoct Orenburgskoy Oblasti. Orenburgskoe Knizhnoe Izdatelstvo, pp. 28-31. 
Pemberton, G. and Gingras, M. (2005). Classification and characterizations of biogenically enhanced permeability. AAPG Bulletin, 11: 1497-1498.

Pemberton, S.G. and Frey, R.W. (1982). Trace fossil nomenclature and the planolites- palaeophycus dilemma. Journal of Paleontology, 56(4): 848-849, SEPM Society for Sedimentary Geology.

Peterson, J.A. and Clarke, J.W. (1983a). Petroleum geology and resources of the Volga-Ural Province, U.S.S.R. United States Department of the interior. Geological Survey Circular, 885: 17.

Peterson, J.A. and Clarke, J.W. (1983b). Geology of the Volga-Ural Petroleum Province and detailed description of the Romashkino and Arlan oil fields. United States Department of the Interior Geological Survey, pp. 22-23.

Posamentier, H.W. and Allen, G.P. (1999). Siliciclastic sequence stratigraphy: concepts and applications. Volume 7 of concepts in sedimentology and paleontology. SEPM (Society for Sedimentary Geology), Tulsa, Oklahoma, pp. 204.

Reinson, G.E. (1984). Barrier island and associated strand plain system. In: Walker, R.G. (Ed.), Facies models, geoscience Canada reprint series, Vol. 1, pp. 119-140.

Reinson, G.E. (1992). Transgressive barrier island and estuarine systems. In: Walker, R.G. and James, N.P. (Eds.), Facies models. Geological association of Canada, pp. 179-194.

Schieber, J (2002). The role of an organic slime matrix in the formation of pyritized burrow trails and pyrite. Palaios, 17: 104-109.

Schieber, J., Bose, P.K., Eriksson, P.G., Banarjee, S., Sarkar, S., Altermann, W., and Catuneanu, O. (Eds.), (2007). Atlas of microbial mat features preserved within the siliciclastic rock record, pp. 20-25.

Senior, P.J. and Walton, A.W. (2011). Depositional environment, reservoir properties, and tertiary oil recovery consideration of a Chesterian (Upper Mississippian) incised-valley fill: Pleasant Prairie Oilfield, Haskell County, Kansas. Search and Discovery Article \#50515: 1-4.

Sexton, W.J. and Hayes, M.O. (1996). Holocene deposits of reservoir-quality sand along the central South Carolina coastline. AAPG Bulletin, 80: 831-855.

Shudova, S.D. (1975). Detalnoe stratigraficheskoe raschenenie Kzanskih otlozheniy mezhdurechya Buzuluka- Ika. In: Guseva, M. (Ed.), Geologia I razrabotka neftyanih I gazovih mestorozhdeniy Orenburgskoy oblasti. Ministerstvo Geologii SSSR, Pribolzhskoe Knizhnoe Izdatelstvo Saratov, pp. 11-19.

Suharevich, P.M., Kaydalov, V.I., and Chikin, M.N. (1975). Razmeshenie resursov nefti I gaza I osnovnie napravlenia poiskovo- razvedochnih rabot na territorii Orenburgskoy oblasti. In: Guseva, M. (Ed.), Geologia I razrabotka neftyanih I gazovih mestorozhdeniy Orenburgskoy Oblasti. Ministerstvo Geologii SSSR, Pribolzhskoe Knizhnoe Izdatelstvo Saratov, pp. 3-10.

Sylvester, Z. and Lowe, D.R. (1978). Fluid escape structure. In: Sedimentology - Encyclopedia of Earth Science. Springer, Berlin.

Tonkin, N.S. (2012). Deltas. Trace fossils as indicators of sedimentary environments. Developments in Sedimentology, 64, 507-528, Elsevier.

Travina, L.M. (1975). Tipi razrezov kamennougolnih otlezhenii v svyazi s tektonicheskim razvitiem territorii Orenburgskoy oblast. In: Guseva, M. (Ed.), Geologia i razrabotka neftyanih $i$ gazovih mestorozhdeniy Orenburgskoy Oblasti. Ministerstvo Geologii SSSR, Pribolzhskoe Knizhnoe Izdatelstvo Saratov, pp. 20-26.

Van Wagoner, J.C., Mitchum, R.M., Campion, K.M., and Rahmanian, V.D. (1990). Siliciclastic sequence stratigraphy in well logs, cores, and outcrops: concepts for high-resolution correlation of time and facies. AAPG Methods in Exploration Series, 7.AAPG, Tulsa, OK, USA, pp. 55.

Wilgus, C.K., Hastings, B.S., St, C.G., Kendall, C., Posamentier, H.W., Ross, C.A., and Van Wagoner, J.C. (Eds.), (1988). Sea level changes: an integrated approach. Society of Economic Paleontologists and Mineralogists Special Publication, 42: 392.

Zaitlin, B.A., Dalrymple, R.W., Boyd, R., and Leckie, D. (1994b). The stratigraphic organization of incised valley systems - implications to hydrocarbon exploration and production: Calgary, Alberta, Canada. Canadian Society of Petroleum Geologists.

Zaitlin, B.A., Dalrymple, R.W., and Boyd, R. (1994a). The stratigraphic organization of incised-valley systems associated with relative sea-level changes. In: Dalrymple, R.W., Boyd, R., and Zaitlin, B.A. (Eds.), Incised valley systemsorigin and sedimentary sequences: SEPM Special Publication, 51, pp. $45-50$.

Zecchin, M. (2007). The architectural variability of small-scale cycles in shelf and ramp clastic systems: the controlling factors. Earth-Science Reviews, 84: 21-55.

Zecchin, M. and Catuneanu, O. (2019). Wave-ravinement surfaces: classification and key characteristics. Earth-Science Reviews, 188: 210-239.

Zonenshain, L.P., Korinevsky, V.G., Kazmin, V.G., Pechersky, D.M., Khain, V.V., and Matveenkov, V.V. (1984). Plate tectonic model of the south Urals development. Tectonophysics, 109: 95135.

\footnotetext{
Open Access. This is an open-access article distributed under the terms of the Creative Commons Attribution-NonCommercial 4.0 International License (https:// creativecommons.org/licenses/by-nc/4.0/), which permits unrestricted use, distribution, and reproduction in any medium for non-commercial purposes, provided the original author and source are credited, a link to the CC License is provided, and changes - if any - are indicated.
} 